\title{
The Role of Potassium and Host Calcium Signaling in Toxoplasma gondii egress
}

Stephen A. Vella ${ }^{1,2}$, Christina A. Moore ${ }^{1,3}$, Zhu-Hong Li $^{1}$, Miryam A. Hortua

Triana $^{1}$, Evgeniy Potapenko ${ }^{1}$ and Silvia N J Moreno ${ }^{1,3, *}$

From the ${ }^{1}$ Center for Tropical and Emerging Global Diseases, ${ }^{2}$ Department of Microbiology and ${ }^{3}$ Department of Cellular Biology, University of Georgia, Athens, GA, 30602

Running title: Host calcium and Toxoplasma egress

*Corresponding author: smoreno@uga.edu

Keywords: Toxoplasma gondii, calcium signaling, genetically-encoded calcium indicators, GCaMP6f, RGECO, LAR-GECO, jGCaMP7f, Toxoplasma egress 


\begin{abstract}
Toxoplasma gondii, an obligate intracellular parasite, is capable of invading virtually any nucleated cell. $\mathrm{Ca}^{2+}$ signaling is universal and both $T$. gondii and its mammalian host cell will utilize $\mathrm{Ca}^{2+}$ signaling to stimulate diverse cellular functions. Egress of $T$. gondii from the host cell is an essential step for the infection cycle of $T$. gondii and a cytosolic $\mathrm{Ca}^{2+}$ increase initiates the $\mathrm{Ca}^{2+}$ signaling cascade that culminates in stimulation of motility and egress. In this work we demonstrate that intracellular T. gondii is capable of taking up $\mathrm{Ca}^{2+}$ from the host cytoplasm when this concentration is increased during host signaling events. Both intracellular and extracellular $\mathrm{Ca}^{2+}$ sources are important to reach a threshold of cytosolic $\mathrm{Ca}^{2+}$ needed for a successful egress. Two peaks of $\mathrm{Ca}^{2+}$ were observed in single parasites that egressed with the second peak resulting from $\mathrm{Ca}^{2+}$ influx. We patched infected host cells to allow a precise delivery of exact concentrations of $\mathrm{Ca}^{2+}$ for stimulating motility and egress. Using this approach, we found that low potassium concentration modulates but do not trigger host cell egress. This is the first study using whole-cell patches to study the role of ions such as $\mathrm{K}^{+}$and $\mathrm{Ca}^{2+}$ in $T$. gondii egress.
\end{abstract}

\title{
Introduction
}

The pathogenesis caused by the infection with Toxoplasma gondii is linked to the ability of the parasite to engage in multiple rounds of a lytic cycle which consists of invasion of host cells, replication inside a parasitophorous vacuole (PV), and egress resulting in lysis of the host cell, followed by invasion of a new host cell $(1,2)$. Several key steps of the lytic cycle of $T$. gondii: egress, invasion, attachment, and motility, are regulated by fluctuations in cytosolic $\mathrm{Ca}^{2+}$ concentrations $(3,4)$.

$\mathrm{Ca}^{2+}$ is a universal signaling molecule and plays important roles in the regulation of a large number of cellular functions (5). The cytosolic concentration of $\mathrm{Ca}^{2+}$ is highly regulated, because prolonged high cytosolic $\mathrm{Ca}^{2+}$ levels are toxic and may result in cell death. A variety of $\mathrm{Ca}^{2+}$ pumps, channels, and transporters, located at the plasma membrane (PM) and to intracellular stores (endoplasmic reticulum (ER), acidic stores and mitochondria) are involved in maintaining cytosolic $\mathrm{Ca}^{2+}$ levels under control (5).

In Toxoplasma $\mathrm{Ca}^{2+}$ signaling initiates a chain of events that leads to the activation of specific effectors involved in the regulation of motility as gliding parasites loaded with fluorescent 
$\mathrm{Ca}^{2+}$ indicators, as well as expressing Genetically Encoded Calcium Indicators (GECIs) show $\mathrm{Ca}^{2+}$ oscillations $(6,7)$. Previous studies have shown that increasing cytoplasmic $\mathrm{Ca}^{2+}$ activates the motility machinery leading to egress. Blocking these cytosolic $\mathrm{Ca}^{2+}$ fluxes using BAPTA-AM (membrane permeable cytosolic $\mathrm{Ca}^{2+}$ chelator), blocks motility, conoid extrusion (apical tip of cell necessary for attachment), invasion, and host cell egress (8).

Active egress of Toxoplasma from host cells requires rupture of the parasitophorous vacuole membrane (PVM) and the host cell membrane (9). Egress is essential for the dissemination of the infection and it has been known for several years that $\mathrm{Ca}^{2+}$ ionophores can trigger egress (10). However, it was the use of GECIs that provided the final and conclusive evidence that there was a cytosolic $\mathrm{Ca}^{2+}$ increase right before egress (7). Secretion of the perforin-like protein 1 (TgPLP1) from micronemes (specialized secretory organelles involved in egress, motility, and invasion by tachyzoites), assists in the permeabilization of the PVM and host cell membrane (11). Both secretion of the microneme protein TgPLP1 and initiation of motility during egress are stimulated by an increase in cytosolic $\mathrm{Ca}^{2+}$. It has been proposed that the trigger for this cytosolic $\mathrm{Ca}^{2+}$ increase is the rupture of the host plasma membrane and the ensuing reduction in the concentration of cytoplasmic potassium. Low $\left[\mathrm{K}^{+}\right]$would activate a phospholipase $\mathrm{C}$ activity in Toxoplasma that, in turn, would cause an increase in cytoplasmic $\left[\mathrm{Ca}^{2+}\right]$ in the parasite (12).

As an obligate intracellular parasite, $T$. gondii resides and replicates within the PV that functions as a molecular sieve to passively permit the exchange of small molecules; thus, the surrounding milieu of intracellular parasites is likely in equilibrium with the host cell cytoplasm (13). Therefore, intracellular parasites are likely exposed to the fluctuations of the host cytosolic ionic composition. The host cytoplasmic $\mathrm{Ca}^{2+}$ level is highly controlled and kept at physiological levels of $\sim 70-100 \mathrm{nM}$ under basal conditions, which is similar to the cytoplasmic levels of the replicating parasites. Experimental evidence indicates that $\mathrm{Ca}^{2+}$ efflux from intracellular stores represent the first initial step of the $\mathrm{Ca}^{2+}$ signaling pathway for egress, so maintaining the high $\mathrm{Ca}^{2+}$ levels of the stores is fundamental for continuation of the lytic cycle.

In this work, we investigated both the ability of Toxoplasma to replenish its intracellular $\mathrm{Ca}^{2+}$ stores during its replication and the role of low $\left[\mathrm{K}^{+}\right]$as a trigger for host cell egress. Using a variety of pharmacological tools, fluorescence microscopy, and a novel approach using patched host cells, we show that $\mathrm{Ca}^{2+}$ signaling of the host cell impacts parasite $\mathrm{Ca}^{2+}$ levels and drives parasite egress, while low $\left[\mathrm{K}^{+}\right]$modulates but is not the trigger for parasite egress. 


\section{Results}

\section{Calcium influx in intracellular parasites}

We previously characterized a $\mathrm{Ca}^{2+}$ influx pathway at the plasma membrane of extracellular $T$. gondii. Following on this finding we wanted to determine if $\mathrm{Ca}^{2+}$ influx was also operational in intracellular replicating parasites. For this we measured cytosolic $\mathrm{Ca}^{2+}$ responses of intracellular tachyzoites and exposed them to fluctuations of host cytosolic $\mathrm{Ca}^{2+}$ by stimulating them with a variety of agonists that act specifically on the host cell. We used Genetically Encoded $\mathrm{Ca}^{2+}$ Indicators (GECIs) $(14,15)$ expressed in the cytosol of HeLa cells infected with $T$. gondii tachyzoites expressing either cytosolic GCaMP6f or luminal PV targeted jGCaMP7f (16) (See Material and Methods and Table S1). We grew HeLa cells on coverslips, transfected them with red GECIs and infected these cells with green GECI-expressing tachyzoites. To follow $\mathrm{Ca}^{2+}$ changes, we used time-lapse microscopy and stimulated them with specific host cell agonists (Figs 1 and S1). We first used carbachol, a muscarinic receptor agonist that specifically acts on mammalian host cells and stimulates $\mathrm{Ca}^{2+}$ oscillations (17). Muscarinic receptors, stimulated by the neurotransmitter acetylcholine, are well-characterized G-coupled protein receptors that lead to an increase in cytosolic $\mathrm{Ca}^{2+}$ via activation of a phosphatidyl inositol phospholipase C (PI-PLC) and generation of inositol 1,4,5-trisphosphate ( $\left.\mathrm{IP}_{3}\right)(18)$. Carbachol addition resulted in a dramatic rise in the fluorescence of RGECO or jRGECO1a, indicating an increase in host cytosolic $\mathrm{Ca}^{2+}$ (Fig 1A, red tracings). For the experiment shown in Fig 1A, the tachyzoites expressed jGCaMP7f in the PV, which was achieved by fusing the T. gondii $\mathrm{P} 30$ gene to the $\mathrm{N}$-terminus of the GECI, which was shown to confer localization to the PV (11). An almost simultaneous rise in $\mathrm{PV} \mathrm{Ca}^{2+}$ and host $\mathrm{Ca}^{2+}$ was observed (Fig 1A, green tracing) thereby supporting the molecular sieve model of the PV (13). We also tested if the parasite cytosolic $\mathrm{Ca}^{2+}$ also increased following host cytosolic $\mathrm{Ca}^{2+}$ stimulation thus supporting $\mathrm{Ca}^{2+}$ influx from the host cytosol to the parasite. HeLa cells expressed a cytosolic copy of RGECO and were infected with tachyzoites expressing GCaMP6 $f$ in their cytoplasm (Fig 1B, green tracing and Supplemental Video 1). $\mathrm{Ca}^{2+}$ influx into the intracellular tachyzoite was also observed in experiments using HeLa cells infected with parasites expressing GCaMP6f in their cytosol and RGECO localized to the lumen of the PV. Carbachol addition caused a uniform rise in all PVs expressing the GECI, followed by a small proportion of 
parasites showing increase in cytosolic $\mathrm{Ca}^{2+}$ (GCaMP6f signal) (Fig 1C). It is possible that this phenotype represents parasites at different stages of the replication cycle that are more or less sensitive to $\mathrm{Ca}^{2+}$ influx. All parasites within the same PV were exposed to the same rise in luminal PV Ca ${ }^{2+}$ because all PV's responded to carbachol stimulation (Fig 1A), yet only a few parasites showed a subsequent increase in parasite cytosolic $\mathrm{Ca}^{2+}$ (Fig 1B).

We repeated our experiments assessing the $\mathrm{Ca}^{2+}$ waves between host-PV-parasite cytosol by stimulating host $\mathrm{Ca}^{2+}$ increase using histamine (Fig S1). Histamine functions through a similar, though different G-coupled protein receptor than carbachol. Histamine will also induce an $\mathrm{IP}_{3}$ mediated increase in cytosolic $\mathrm{Ca}^{2+}(19)$. The results with histamine were similar to the ones with carbachol in which a rise in host cell $\mathrm{Ca}^{2+}$ occurred simultaneous with $\mathrm{PV} \mathrm{Ca}^{2+}$. Additionally, parasite $\mathrm{Ca}^{2+}$ influx trailed host $\mathrm{Ca}^{2+}$. These results demonstrate that intracellular tachyzoites are able to take up $\mathrm{Ca}^{2+}$ from the host $\mathrm{Ca}^{2+}$ cytosol following $\mathrm{Ca}^{2+}$ signaling events.

\section{A Threshold of $\mathrm{Ca}^{2+}$ is needed for Parasite Egress}

To visualize the link between host $\mathrm{Ca}^{2+}$ signaling and intracellular parasite $\mathrm{Ca}^{2+}$ fluctuations and egress, we transiently transfected HeLa cells with LAR-GECO1.2 (a red $\mathrm{Ca}^{2+}$ indicator optimized for expression within the host mitochondria) (20) and infected the host cells with cyto-GCaMP6f expressing tachyzoites. We stimulated $\mathrm{Ca}^{2+}$ with ionomycin, a $\mathrm{Ca}^{2+} / \mathrm{H}^{+}$ionophore which causes $\mathrm{Ca}^{2+}$ release from all neutral stores (21), or thapsigargin (TG), an inhibitor of the endoplasmic reticulum (ER) $\mathrm{Ca}^{2+}$-ATPase SERCA (Fig 2A\&B) (22). The ER constantly allows efflux of $\mathrm{Ca}^{2+}$ via an unknown mechanism, and the SERCA serves as a counterbalance to pump $\mathrm{Ca}^{2+}$ back into the organelle. Blocking of SERCA via thapsigargin will induce a rise in cytosolic $\mathrm{Ca}^{2+}$ due to the ER's constant efflux of $\mathrm{Ca}^{2+}(22)$. The addition of ionomycin leads to a dramatic $\mathrm{Ca}^{2+}$ increase in both host cell and parasite, followed by rapid egress (Fig 2A\&C). TG induced an increase in the fluorescence of LAR-GECO, indicating an increase of $\mathrm{Ca}^{2+}$ within the host mitochondria (LARGECO), as well as $\mathrm{Ca}^{2+}$ oscillations within the parasite (GCaMP6f). The increase in host mitochondrial $\mathrm{Ca}^{2+}$ can be accounted for as due to the close, tight interaction between the ER and the mitochondria (23). Interestingly, addition of TG caused $\mathrm{Ca}^{2+}$ oscillations in the intracellular tachyzoites but they remained intracellular throughout all $10 \mathrm{~min}$ of recording (Fig 2B\&D and Supplemental Video 2). 
We next tested Zaprinast, a cGMP phosphodiesterase inhibitor, which inhibits the cGMP phosphodiesterase resulting in a build-up of cGMP that activates protein kinase G (PKG) leading to an increase of cytosolic $\mathrm{Ca}^{2+}$ and stimulation of egress $(24,25)$. The increase of cytosolic $\mathrm{Ca}^{2+}$ by Zaprinast was almost comparable to the increase observed with ionomycin, and also resulted in egress (Fig 2E). However, while both histamine and thapsigargin did induce an increase in parasite cytosolic $\mathrm{Ca}^{2+}$, the response was insufficient to induce egress. Ionomycin and Zaprinast produced a $\Delta \mathrm{F}_{\max } / \mathrm{F}_{0}$ of approximately 6 that was not statistically different between the two. Thapsigargin or histamine $\Delta \mathrm{F}_{\max } / \mathrm{F}_{0}$ responses were much lower of approximately $\sim 2$ fold and was not statistically different between the two reagents. Comparing the results with Ionomycin to those with either thapsigargin or histamine and the results with Zaprinast to those of either thapsigargin or histamine, show that the responses were statistically different (Fig 2E). Our results suggest that a threshold for cytosolic $\mathrm{Ca}^{2+}$ has to be met in order to induce egress.

With the aim of estimating the $\mathrm{Ca}^{2+}$ threshold needed, we titrated down ionomycin to determine a concentration that would still produce a $\mathrm{Ca}^{2+}$ response but was insufficient to induce egress. Ionomycin at $1 \mu \mathrm{M}$ induced a rapid egress response (Fig $2 \mathrm{~F} \& \mathrm{H}$ ), and titrating down the concentration of ionomycin to $0.1 \mu \mathrm{M}$ and $0.01 \mu \mathrm{M}$ led to a decrease in the $\Delta$ Fluorescence response, though parasite egress was still observed. No egress was observed when the ionomycin concentration was lowered to $0.005 \mu \mathrm{M}$ (Fig 2G\&I). It is significant to note that the $\Delta$ Fluorescence response of $0.005 \mu \mathrm{M}$ was approximately 3, a value closely similar to the responses of thapsigargin and histamine that also did not produce a sufficient response to induce egress (Fig 2E\&J). The cytosolic $\mathrm{Ca}^{2+}$ concentration that tachyzoites reached in response to various concentrations of Ionomycin were evaluated in a separate experiment with extracellular tachyzoites loaded with the ratiometric $\mathrm{Ca}^{2+}$ indicator Fura-2-AM (Fig S3). The cytosolic concentration reached for Ionomycin at $5 \mathrm{nM}$ was $\sim 250 \mathrm{nM}$ and at $10 \mathrm{nM}$ was around $750 \mathrm{nM}$. From these experiments we could conclude that there is a cytosolic $\mathrm{Ca}^{2+}$ threshold that needs to be reached for the stimulation of egress and it is around 300-500 nM.

\section{Two Peaks of $\mathrm{Ca}^{2+}$ Lead to Parasite Egress}

To further characterize the $\mathrm{Ca}^{2+}$ response of intracellular parasites and the ensuing egress we tested Zaprinast, which will result in $\mathrm{Ca}^{2+}$ increase and stimulation of microneme secretion, and parasite egress. This experiment was done in the presence of extracellular buffer supplemented with $2 \mathrm{mM}$ 
$\mathrm{Ca}^{2+}$ and we noticed that egressing parasites displayed a quantifiable, characteristic two fluorescence peaks that preceded egress (Fig 3A-C and Supplemental Video 3). We repeated the Zaprinast induced egress experiments with extracellular buffer supplemented with $100 \mu \mathrm{M}$ EGTA $\left(\mathrm{Ca}^{2+}\right.$ free) and quantified the response. Under these conditions the second fluorescence peak was lower and wider (Fig 3D-F). Parasites took longer to egress when Zaprinast was added in $\mathrm{Ca}^{2+}$ free buffer compared to egress in extracellular buffer supplemented with $2 \mathrm{mM} \mathrm{Ca}^{2+}$ (Fig 3F).

We next compared the parasite cytosolic $\mathrm{Ca}^{2+}$ fluctuations after permeabilizing the host cell with saponin under two conditions: $\mathrm{Ca}^{2+}$ free $\left(100 \mu \mathrm{M}\right.$ EGTA) and $\mathrm{Ca}^{2+}$ rich $\left(2 \mathrm{mM} \mathrm{Ca}^{2+}\right)$ buffers (Fig. G-J). Without extracellular $\mathrm{Ca}^{2+}$, egress was not observed, though a sharp single peak was evident after quantifying the fluorescence tracings (Fig 3G-H). In comparison, when using a $\mathrm{Ca}^{2+}$ rich buffer after permeabilizing the host membrane to expose the parasites to the extracellular buffer, cytosolic $\mathrm{Ca}^{2+}$ levels oscillated and they promptly egressed from their respective PV's (Fig 3I-J). In the presence of extracellular $\mathrm{Ca}^{2+}$ two peaks of $\mathrm{Ca}^{2+}$ were observed (Fig. 3J).

The microneme protein Perforin-Like Protein 1 (PLP1) functions in breaking down the host cell during egress, exposing intracellular tachyzoites to the surrounding extracellular milieu. PLP1 has been shown to be involved in the initial rupture of the PV (11) and the release of $\mathrm{Ca}^{2+}$ from intracellular stores could stimulate this release in the natural egress process. Our model proposes that this rupture would allow the extracellular $\mathrm{Ca}^{2+}$ to influx the parasites contributing to reaching the threshold for downstream stimulation of gliding motility and egress. We tested whether $\triangle$ PLP1 mutants, defective in their ability to breakdown the host cell, would still display two peaks during egress. We transfected GCaMP6f into $\triangle$ PLP1 mutants and induced egress using $100 \mu \mathrm{M}$ Zaprinast (Fig S2). We quantified the fluorescence tracings of egressing parasites and these cells only displayed 1 peak (Fig S2B \&C) supporting that the second peak is due to influx from the extracellular milieu.

These experiments demonstrate that intracellular tachyzoites are capable of taking up $\mathrm{Ca}^{2+}$ from the host cytosol and also from the extracellular milieu after host cell rupture which results in a second peak of cytosolic $\mathrm{Ca}^{2+}$ that precedes egress.

\section{$\mathrm{A} \mathrm{Ca}^{2+}$ Peak Precedes Natural Egress from Host Cells}

With the aim of investigating the presence of two peaks of cytosolic $\mathrm{Ca}^{2+}$ during natural egress we synchronized intracellular parasites using compound 1 (cpd1) (Fig 4 and Supplemental Video 4). 
In the related Apicomplexa parasite Plasmodium falciparum, cpd1 reversibly inhibits PKG and arrests parasites from egressing (26). We pre-incubated HeLa cells expressing jRGECO1a and infected with GCaMP6f- expressing tachyzoites with cpdl for $24 \mathrm{~h}$ to arrest egress. At this time, we washed off cpd1 and egress was observed within approximately two min preceded by an increase in cytosolic $\mathrm{Ca}^{2+}$. The increase began with a single "leader" tachyzoite that was distinguishable due to having the largest rise in cytosolic $\mathrm{Ca}^{2+}$ and this cell egressed first (Fig 4 A). We quantified the fluorescence tracings, and as expected, egressing parasites displayed two peaks during egress (Fig $4 \mathrm{C}$-E). Interestingly, a rise in host $\mathrm{Ca}^{2+}$ was also evident during the natural egress process, thus highlighting the role of extracellular $\mathrm{Ca}^{2+}$ influx during natural egress (Fig. 4C\&D, red tracing). Next we tested how $\triangle \mathrm{PLP} 1$ parasites would respond under natural egress conditions (Fig. 4B\&F). Post cpd1 washout, $\triangle \mathrm{PLP1}$ GCaMP6f oscillated randomly and nonuniformly, and no parasite exhibited the two-peak pattern observed in wild type parasites (Fig. 4F). Some parasites displayed movement within the PV of the $\triangle$ PLP1 parasites(11) post rise in cytosolic $\mathrm{Ca}^{2+}$ though none of these parasites displayed a second peak of higher amplitude that would be associated with $\mathrm{Ca}^{2+}$ influx, as well as no rise in the jRGECO1a channel that would be indicative of rupture of the host cell and extracellular $\mathrm{Ca}^{2+}$ influx. Eventually the fluorescence of these parasites diminished indicating lower cytosolic $\mathrm{Ca}^{2+}$, and the parasites stopped moving shortly after. Given these results, we conclude that two-peaks of $\mathrm{Ca}^{2+}$ are part of the natural egress progression of $T$. gondii and the second peak is due to $\mathrm{Ca}^{2+}$ influx from the extracellular milieu.

\section{Blocking $\mathrm{Ca}^{2+}$ Influx Using Pharmacological Agents Blocks Parasite Egress}

With the aim of characterizing further the source of the two peaks of $\mathrm{Ca}^{2+}$ we tested some pharmacological agents. We first tested nifedipine, a voltage-gated $\mathrm{Ca}^{2+}$ channel inhibitor and pretreated intracellular cyto-GCaMP6f-expressing parasites with the drug to compare egress with control parasites (Fig. 5A). The surrounding extracellular buffer was supplemented with $2 \mathrm{mM}$ $\mathrm{Ca}^{2+}$ and the host cells were permeabilized with saponin. While the control non-treated parasites egressed following a sharp rise in cytosolic $\mathrm{Ca}^{2+}$ trailed by smaller $\mathrm{Ca}^{2+}$ oscillations (Fig 5A \&B) the nifedipine treated parasites did not egress, and showed only modest $\mathrm{Ca}^{2+}$ oscillations of approximately two-fold range (Fig 5C\&D), which are below the threshold needed for egress (Fig 2). We next tested cpd1 to inhibit PKG and induced egress with Zaprinast. While control parasites egressed following a fast rise in cytosolic $\mathrm{Ca}^{2+}$ with two peaks (Fig 5E\&F), pretreatment with cpd1 
abolished egress, and the parasites' cytosolic $\mathrm{Ca}^{2+}$ only raised about 3-fold (Fig 5G\&H). These results showed that blocking extracellular $\mathrm{Ca}^{2+}$ influx with nifedipine or inhibiting PKG, results in intracellular parasites that are unable to reach the threshold needed for egress, in support for the role of extracellular $\mathrm{Ca}^{2+}$ influx in egress.

\section{Role of $\mathrm{K}^{+}$and $\mathrm{Ca}^{2+}$ in parasite egress}

The cytosol of eukaryotic cells contains approximately $140 \mathrm{mM} \mathrm{K}^{+}$with $70-90 \mathrm{nM} \mathrm{Ca}^{2+}$, while the extracellular milieu contains $5 \mathrm{mM} \mathrm{K}^{+}$and $\sim 1.8 \mathrm{mM} \mathrm{Ca}^{2+}$. During a $\mathrm{Ca}^{2+}$ signaling event, cytosolic $\mathrm{Ca}^{2+}$ rises rapidly to $\mu \mathrm{M}$ levels (5), and we have shown that a crosstalk exists between the host cell and the parasite cytosolic $\mathrm{Ca}^{2+}$ (Fig 1). To manipulate the host cytosolic ionic composition, and identify the $\mathrm{Ca}^{2+}$ concentration that would induce parasite egress, we patched infected HeLa cells (27). We attached a pipet to the plasma membrane of infected cells as shown in Fig 6A, formed a patch seal between the plasma membrane and the pipette, and broke the plasma membrane, thus equilibrating the solution in the patch pipette with the cytosol of the host cell. This technique allowed us to control the composition of the buffer surrounding the PVs by modifying the pipet buffer (Fig 6A). We tested increasing concentrations of cytosolic free $\mathrm{Ca}^{2+}(0.5,1,5$, and $10 \mu \mathrm{M})$ in a $140 \mathrm{mM} \mathrm{K}^{+}$patch pipette solution (Fig. 6B). We did not observe egress at $0.5 \mu \mathrm{M} \mathrm{Ca}^{2+}$, and only a small percentage of parasites egressed at $1 \mu \mathrm{M} \mathrm{Ca}^{2+}$. Approximately one third of parasites egressed when exposed to $5 \mu \mathrm{M} \mathrm{Ca}^{2+}$ while the remaining two thirds did not egress. Ultimately at a concentration of $10 \mu \mathrm{M} \mathrm{Ca}^{2+}$, all parasites egressed (Supplemental Video 5). Previous literature has stated that the high potassium concentration of the host cytosol prevented parasite egress. It was postulated that a decrease in the concentration of $\mathrm{K}^{+}$would activate a $\mathrm{Ca}^{2+}$ signal, inducing microneme secretion and subsequent egress (12). To test the role of $\mathrm{K}^{+}$in parasite egress, we repeated the whole-cell patch in a low potassium solution within the patch pipette (Fig 6C). Choline chloride was added to maintain the same osmolarity and anionic composition. Under low potassium, we did not observe egress at $0.5 \mu \mathrm{M} \mathrm{Ca}^{2+}$, and two thirds of the parasites of the patched cells egressed at $1 \mu \mathrm{M} \mathrm{Ca}^{2+}$, and parasites egressed faster compared to their high potassium counterpart. Approximately $80 \%$ of parasites egressed at $5 \mu \mathrm{M} \mathrm{Ca}^{2+}$, and egress occurred in approximately $3 \mathrm{~min}$ compared to $5 \mathrm{~min}$ in high $\mathrm{K}^{+}$. Similar to the high potassium conditions, 10 $\mu \mathrm{M} \mathrm{Ca}^{2+}$ caused $100 \%$ egress, but again at a much faster rate. We summarized our patch data in 
Fig. 6D\&E. No egress was observed under both conditions for $0.5 \mu \mathrm{M} \mathrm{Ca}^{2+}$, for both conditions and percentage and rate of egressing parasites was higher and faster under low potassium conditions. As we increased the cytosolic $\mathrm{Ca}^{2+}$ concentration to 2,5 , and $10 \mu \mathrm{M} \mathrm{Ca}{ }^{2+}$, the percentage of egressing parasites increased quasi-linearly under the low potassium conditions. Under high potassium conditions the percentage of egressing parasites increased quasi-linearly from 1-5 $\mu \mathrm{M} \mathrm{Ca}^{2+}$, but $10 \mu \mathrm{M} \mathrm{Ca}^{2+}$ was sufficient to induce $100 \%$ egress (Supplemental Video 6). At $1 \mu \mathrm{M} \mathrm{Ca}^{2+}$, parasites egressed in approximately 550 and $320 \mathrm{sec}$ for high and low potassium, respectively. In high potassium conditions, parasites egressed at about the same rate for 2 and 5 $\mu \mathrm{M} \mathrm{Ca}^{2+}$, but under low potassium conditions parasites egressed faster at $5 \mu \mathrm{M} \mathrm{Ca}^{2+}$ versus $2 \mu \mathrm{M}$ $\mathrm{Ca}^{2+}\left(\sim 300\right.$ seconds $\left(2 \mu \mathrm{M} \mathrm{Ca}^{2+}\right)$ versus $\sim 200$ seconds $\left.\left(5 \mu \mathrm{M} \mathrm{Ca}^{2+}\right)\right)$. Though $100 \%$ egress was observed at $10 \mu \mathrm{M} \mathrm{Ca}^{2+}$ for both conditions, in high potassium parasites egressed in $\sim 250$ seconds, versus $\sim 50$ seconds in low potassium conditions. In summary, according to these results $\mathrm{Ca}^{2+}$ is crucial for egress but a decrease in the concentration of $\mathrm{K}^{+}$as the parasite lyses the host cell and egresses, results in acceleration but is not the trigger for egress.

\section{Discussion}

Our work shows that $\mathrm{Ca}^{2+}$ influx into the parasite during host physiological $\mathrm{Ca}^{2+}$ signaling events (i.e. stimulation of GPCR, VGCC, etc) could be the means the parasite uses to replenish its intracellular $\mathrm{Ca}^{2+}$ stores depleted after host cell invasion. Intracellular tachyzoites via the PV are exposed to the low $\mathrm{Ca}^{2+}$ concentration (70-100 nM) present in the host cytosol while extracellular tachyzoites are surrounded by high $\mathrm{Ca}^{2+}(1.8-2.0 \mathrm{mM})$. Considering that egress can occur at nearly any stage of intracellular replication and is preceded by a spike in cytosolic $\mathrm{Ca}^{2+}(7)$, that very likely is initiated by intracellular store release, intracellular replicating $T$. gondii needs to maintain its intracellular stores filled with $\mathrm{Ca}^{2+}(7)$.

Our results revealed that either under conditions of natural egress (after cpd1 egress arrest), or after treatment with pharmacological agents (zaprinast, saponin), two peaks of cytosolic $\mathrm{Ca}^{2+}$ increase occur in tachyzoites, the first one probably of intracellular store origin and the second peak associated with $\mathrm{Ca}^{2+}$ entry. In support of this statement, the second peak was absent after treatment with nifedipine, an agent previously found to be a $\mathrm{Ca}^{2+}$ entry inhibitor (28), and in $\triangle P L P 1$ parasites, suggesting that this $\mathrm{Ca}^{2+}$ entry depends on the permeabilization of the host cell 
plasma membrane by the pore forming protein (PLP1). During natural egress, we consistently observed that, after an intracellular $\mathrm{Ca}^{2+}$ increase, a leading tachyzoite initiated egress via presumably secretion of PLP1, exit from the host cell, and finally rupture of the host plasma membrane. This was followed by the passive exit of the remaining tachyzoites. Our results showed a threshold for the $\mathrm{Ca}^{2+}$ increase that preceded egress, and we calculated this increase to be 300 $500 \mathrm{nM}\left[\mathrm{Ca}^{2+}\right]_{\mathrm{i}}$ in the cytoplasm of tachyzoites. We stimulated host cell $\mathrm{Ca}^{2+}$ signaling with carbachol or histamine or used thapsigargin to cause $\mathrm{Ca}^{2+}$ increase in the cytosol of the host and parasite. These conditions, while causing an increase in $\left[\mathrm{Ca}^{2+}\right]_{\mathrm{i}}$ in tachyzoites, failed to reach the threshold needed for egress. These results demonstrated that parasites can replenish their intracellular stores while taking up $\mathrm{Ca}^{2+}$ from the host cell. Interestingly, treatment with thapsigargin lead to a $\mathrm{Ca}^{2+}$ increase in the host mitochondria surrounding the PV. Our experiments using patched host cells revealed that increasing $\mathrm{Ca}^{2+}$ concentrations in the host cell cytosol alone, presumably mimicking initial $\mathrm{Ca}^{2+}$ changes after plasma membrane rupture, were sufficient to stimulate egress, which was accelerated but not initiated by low $\mathrm{K}^{+}$concentrations.

In our experimental set-up, stimulation of host $\mathrm{Ca}^{2+}$ signaling with known mammalian $\mathrm{Ca}^{2+}$ agonists resulted in host cytosolic $\mathrm{Ca}^{2+}$ increases of $\sim 1-2 \mu \mathrm{M}$. Interestingly, we saw that these low levels of $\mathrm{Ca}^{2+}$ are sufficient to stimulate $\mathrm{Ca}^{2+}$ influx into intracellular parasites followed by $\mathrm{Ca}^{2+}$ oscillations. Cytosolic $\mathrm{Ca}^{2+}$ oscillations in $T$. gondii tachyzoites were previously observed $(6,29)$, a fascinating phenomenon for which we do not have a molecular explanation. It is generally believed that $\mathrm{Ca}^{2+}$ oscillations arise from cyclical release and re-uptake of intracellularly stored $\mathrm{Ca}^{2+}(30)$, and a role for influx through plasma membrane channels has also been demonstrated to be important for the maintenance and delivery of $\mathrm{Ca}^{2+}$ into the cytosol. Because of the apparent digital nature of these $\mathrm{Ca}^{2+}$ oscillations (31), they would be perfectly suited for signaling specific biological responses such as secretion of micronemes, stimulation of motility and egress. It was shown that $\mathrm{Ca}^{2+}$ oscillations in extracellular tachyzoites loaded with $\mathrm{Ca}^{2+}$ dyes were associated with microneme discharge and bursts of motility (6). Changes in the $\mathrm{Ca}^{2+}$ oscillation patterns by pharmacological agents affected microneme secretion and motility $(29,32)$, highlighting the role $\mathrm{Ca}^{2+}$ oscillations in coordinating lytic cycle progression. In the case of intracellular tachyzoites, we believe that $\mathrm{Ca}^{2+}$ oscillations, while being insufficient to stimulate egress they serve to ensure the filling of intracellular stores. These oscillations are the result of $\mathrm{Ca}^{2+}$ release from the ER through an unknown channel, likely gated by $\mathrm{IP}_{3}$ (33), followed by re-uptake likely through the 
SERCA-Ca ${ }^{2+}$ ATPase (29) or the plasma membrane $\mathrm{Ca}^{2+}$ ATPase pump (34). The initial increase of cytosolic $\mathrm{Ca}^{2+}$ would be the result of uptake from the host through an unknown parasite plasma membrane channel and this initial $\mathrm{Ca}^{2+}$ increase would stimulate the activity of the PI-PLC at the plasma membrane $(35,36)$ to synthesize $\mathrm{IP}_{3}$, which would open the ER channel and release $\mathrm{Ca}^{2+}$ into the cytosol thereby potentiating the $\mathrm{Ca}^{2+}$ signals. However, cytosolic $\mathrm{Ca}^{2+}$ levels of the parasite are highly buffered (37), and they will be countered by mechanisms such as the PMCA-ATPase or the SERCA-Ca ${ }^{2+}$-ATPase to bring cytosolic $\mathrm{Ca}^{2+}$ back to normal basal levels (8). Another possible scenario would be that interactions between plasma membrane $\mathrm{Ca}^{2+}$ channels with ER receptors, plus $\mathrm{Ca}^{2+}$ itself (and other ions and signaling molecules) would result in $\mathrm{PM} \mathrm{Ca}^{2+}$ channel openings, a phenomenon similar to what happens in muscle cells, where the Ryanodine Receptor (RyR) is directly or indirectly modulated by the L-type $\mathrm{Ca}^{2+}$ channel, $\mathrm{CaV} 1.1 / 1.2, \mathrm{Ca}^{2+}$ itself, other ions and small molecules, and proteins (38). Amplification of the initial $\mathrm{Ca}^{2+}$ signal occurs through activation of the RyR leading to $\mathrm{Ca}^{2+}$ release from the sarcoplasmic reticulum (5). This second scenario would require close proximity between the ER membrane and the plasma membrane because of the known poor diffusibility of $\mathrm{Ca}^{2+}$ in the cytoplasm of cells (39).

Within host cells parasites are stationary, non-motile, and surrounded by low $\mathrm{Ca}^{2+}$, yet activation by an intrinsic signal like phosphatidic acid, as recently proposed (40), would start a signaling cascade leading to a rise in cytosolic $\mathrm{Ca}^{2+}$ followed by stimulation of motility. Apicomplexan motility functions through a conserved, actomyosin motor that forms a complex termed the glideosome, the main molecular machinery involved in parasite motility, egress, and invasion (9). Within the glideosome, Regulatory Light Chains (MLC1), Essential Light Chains 1 and 2 (ELC1 and ELC2), $\mathrm{Ca}^{2+}$ binding proteins, interact either directly with $\mathrm{Ca}^{2+}$ or via $\mathrm{Ca}^{2+}$ dependent phosphorylation events to stimulate motility (41). The binding affinity of ELC is $37 \mu \mathrm{M}$ (41), a concentration that would only be physiologically possible to reach if we accept/consider the presence of $\mathrm{Ca}^{2+}$ microdomains (confined regions of elevated $\mathrm{Ca}^{2+}$ at the site of activated/open channels) at the periphery of the parasite likely formed close to plasma membrane $\mathrm{Ca}^{2+}$ channels. This scenario supports the importance of $\mathrm{Ca}^{2+}$ influx for the stimulation of motility and egress, necessary to activate the glideosome while the overall cytosolic $\mathrm{Ca}^{2+}$ concentration would be maintained low.

It has been proposed that the high $\mathrm{K}^{+}$content of the host cytosol blocks parasite egress (12). When the integrity of the host cell becomes compromised, the $\mathrm{K}^{+}$concentration drops due to 
diffusion into the extracellular media. This drop in the concentration of $\mathrm{K}^{+}$would induce a $\mathrm{Ca}^{2+}$ signal that would stimulate parasite egress through activation of a PI-PLC, though the molecules involved in this model are still unknown $(12,36)$. PI-PLCs of the delta type, like the type present in $T$. gondii (35) are highly sensitive to $\mathrm{Ca}^{2+}$ concentrations and are active at the $\mathrm{Ca}^{2+}$ levels present in the cytoplasm of cells (42). There is no direct connection between PI-PLC activity and $\mathrm{K}^{+}$ concentration but two genes in the T. gondii database (TGME49_238995 and TGME49_273380) are predicted to act as $\mathrm{Ca}^{2+}$-activated $\mathrm{K}^{+}$channels. During intracellular growth, these channels could activate/open in response to $\mathrm{Ca}^{2+}$ release from intracellular stores. Initially, no conductance would occur because the potassium concentration of both parasite and host cytosol would be similar. Lysis of the host cell would result in decrease of the concentration of host cell and PV luminal $\mathrm{K}^{+}$, generating a gradient, and conductance of the ion with loss of $\mathrm{K}^{+}$from the parasite, leading to an unbalance in the intracellular concentration of parasite intracellular $\mathrm{K}^{+}$that would be counteracted by a plasma membrane mechanism such as a potassium/proton exchanger that would exchange $\mathrm{K}^{+}$for $\mathrm{H}^{+}$. This mechanism would lead to acidification of the PV, which has been shown to precede egress (43). T. gondii expresses four predicted sodium proton exchangers and one of them was localized to the plasma membrane of T. gondii (TgNHE1) (TGME49_259200) (44), and a second one (TGME49_263480) is predicted to be at the plasma membrane according to ToxoDB LOPIT (45). It is possible that one of these exchangers could use $\mathrm{K}^{+}$instead of $\mathrm{Na}^{+}$and be responsible for the exchange activity. According to this potential scenario, $\mathrm{Ca}^{2+}$ would be the main trigger and $\mathrm{K}^{+}$would have a modulatory role as we observed with the patch egress experiments.

In summary, we propose that as parasites grow and replicate, host $\mathrm{Ca}^{2+}$ derived from $\mathrm{Ca}^{2+}$ signaling is taken up by parasites through their plasma membrane and pumped into intracellular stores in order to keep them filled during repetitive rounds of replication (Fig. 7). Egress initiates via an unknown signal that induces release of $\mathrm{Ca}^{2+}$ from intracellular stores. Within the PV a leader parasite would respond first with the initial largest $\mathrm{Ca}^{2+}$ increase, which would reach the threshold needed for motility induction and secretion of microneme proteins. Release of PLP1 among other microneme proteins would contribute to the partial breakdown of the host cell (11). This allows for extracellular $\mathrm{Ca}^{2+}$ influx and a drop of host $\mathrm{K}^{+}$, two factors that would both contribute to egress of the remaining parasites. The cycle would continue in the remaining parasites: $\mathrm{Ca}^{2+}$ spike would occur to reach the threshold for secretion of microneme proteins, complete breakdown of the PV membrane and host cell, and a second and more pronounced peak in $\mathrm{Ca}^{2+}$, culminating in egress 
of the entire PV of parasites. We found that the decrease in the concentration of $\mathrm{K}^{+}$plays a role in timing parasite egress, and $\mathrm{Ca}^{2+}$ influx from the host cell or the extracellular milieu would be essential for parasite egress. The data from this work contributes to our knowledge of host-parasite interaction of $T$. gondii and aids in our understanding of the signaling responses that govern parasite egress. The use of whole-cell patching presents a novel methodology to study the role of ions involved in parasite egress, an essential component of the lytic cycle.

\section{Materials and Methods}

\section{Cell Culture}

T. gondii tachyzoites (RH strain) were maintained in hTERT human fibroblasts (BD Biosciences) using Dulbeco's modified essential media (DMEM) with 1\% fetal bovine serum (FBS), as described previously (46). GCaMP6f- transfected tachyzoites were maintained under similar conditions, in the presence of $20 \mu \mathrm{M}$ chloramphenicol. The selection-less strain of GCaMP6f was maintained without drug pressure. hTERT cells were maintained in high glucose DMEM with 10\% fetal calf serum (FCS). HeLa cells (ATCC) were used for egress and whole-cell patch experiments and were maintained in DMEM supplemented with $10 \% \mathrm{FBS}, 1 \mathrm{mM}$ sodium pyruvate, and $2 \mathrm{mM}$ L-glutamine. Cell cultures were grown at $37^{\circ} \mathrm{C}$ with $5 \% \mathrm{CO}_{2}$. Parasites were purified by centrifugation and filtration through a Whatman $8 \mu \mathrm{M}$ nuclepore membrane (GE Healthcare) followed by a second filtration step through a $5 \mu \mathrm{M}$ nuclepore membrane. Filtered parasites were counted and centrifuged following the protocols for each experiment.

\section{Chemicals and Reagents}

Transient transfections were performed using PolyJet that was purchased from SignaGen (http://signagen.com/). Plasmids for GCaMP6f (fast version of GCaMP6), R-GECO1.2, jGCaMP7f, and LAR-GECO1.2 were obtained from Addgene, and the plasmids were used for transient transfection in HeLa cells. The respective genes were cloned into the $T$. gondii expression vector pCTH3 and pDHFRTubGFP for chloramphenicol and selection-less stable expression of GCaMP6f in tachyzoites, respectively. Thapsigargin, ionomycin, saponin, dithiothreitol (DTT), histamine, Zaprinast, and all other chemicals were obtained from Sigma.

\section{Preparation of GECI-expressing Tachyzoites and HeLa Cells}


GCaMP6f expressing parasites were obtained as described previously (7). Briefly, plasmids for expressing GCaMP6f in T. gondii were a gift from Kevin Brown and David Sibley. The coding DNA sequence for GCaMP6f was amplified by PCR and cloned into a $T$. gondii vector for expression downstream the tubulin promoter (pCTH3 and pDTGCaMP6f), using the BglII and AvrII restriction sites and adding a stop codon in front of the GFP sequence. The primers used were forward 5'-AGGCGTGTACGGTGGGAGGTC-3' and reverse 5'CTTCCTAGGTTACTTCGCTGTCATCATTTG-3' (Table S1). The Plasmids were electroporated into the RH strain parasites and clones were selected by chloramphenicol resistance. We then isolated cells with low fluorescence by cell sorting to eliminate those highly fluorescent cells in which the GCaMP6f could be buffering $\mathrm{Ca}^{2+}$ and preventing visualization of physiological changes in $\mathrm{Ca}^{2+}$ levels (47).

HeLa cells $\left(5 \times 10^{5}\right)$ were grown on coverslips in high-glucose DMEM with 10\% FBS. After 24 hours, cells were transfected with $1 \mu \mathrm{g}$ of plasmid DNA encoding RGECO or LAR-GECO1.2 using PolyJet following the instructions of the manufacturer. 6-8 hours later, HeLa cells were infected with $1 \times 10^{6}$ tachyzoites expressing GCaMP6f and were grown for 15-20 hours. Rosettes containing 4-8 parasites were used in all experiments. To construct a cell line of Hela cells stabling expressing the sensitive red GECI, jRGECO1a, the coding sequence of jRGECO1a (14) was PCR amplified with primers Fwd 5'- ACCGGTATGCTGCAGAACGAGCTTGCTCTTA -3' and Rev 5' -GAATTCGCCTACTTCGCTGTCATCATTTGTACA-3' and cloned into the TOPO vector sequence. The resulting product was digested with AgeI and EcoRI restriction enzymes and cloned into the $2^{\text {nd }}$ generation lentivirus expression plasmid pUltra (Table S1). Transfection and cloning of a stable cell line of jRGECO1a was performed using previously established protocols (48). Briefly, $2^{\text {nd }}$ generation viral particles were produced in HEK293T cells, and the viral supernatant was overlaid on Hela cells for spinfection for $2 \mathrm{hr}$. Stable cell lines were enriched and selected using FAC's sorting.

\section{Cytosolic $\mathrm{Ca}^{2+}$ Measurements}

Extracellular tachyzoites of the RH strain were loaded with fura-2-AM as described previously (28). The parasites were washed twice in Ringer buffer (155 mM NaCl, $3 \mathrm{mM} \mathrm{KCL}, 2 \mathrm{mM} \mathrm{CaCl}$, $1 \mathrm{mM} \mathrm{MgCl}_{2}, 3 \mathrm{mM} \mathrm{NaH} \mathrm{PO}_{4}, 10 \mathrm{mM}$ Hepes, $\mathrm{pH}$ 7.3, and $5 \mathrm{mM}$ glucose), resuspended in the 
same buffer to a final density of $1 \times 10^{9}$ cells $/ \mathrm{mL}$, and kept on ice. For fluorescence measurements, $50 \mu \mathrm{L}$-portions of the cell suspension were diluted in $2.5 \mathrm{~mL}$ of Ringer $\left(2 \times 10^{7}\right.$ cells $/ \mathrm{mL}$ final density) in a cuvette placed in a thermostatically controlled Hitachi 4500 spectrofluorometer. Excitation was at $485 \mathrm{~nm}$ and emission at $520 \mathrm{~nm}$. Traces shown are representative of three independent experiments conducted on separate cell preparations. Calcium-defined conditions were determined by using EGTA or 1,2-bis(2-aminophenoxy)ethane- $N, N, N^{\prime}, N^{\prime}$-tetraacetic acid (BAPTA) and calcium chloride to reach specific concentrations of free calcium. Calcium-EGTA combinations were determined using Maxchelator software (https://somapp.ucdmc.ucdavis.edu/pharmacology/bers/maxchelator/downloads.htm).

\section{Egress Assays}

Egress assays were done as described previously (47). HeLa cells were grown in high glucose DMEM with 10\% FBS in $35 \mathrm{~mm}$ glass bottom dishes (MatTek) until confluency. 8-12 hours after transfection, HeLa cells were infected with 1 × $10^{6}$ GCaMP6f-expressing tachyzoites, replacing the media with high glucose DMEM with $1 \%$ FBS. Thirty hours after infection, parasitophorous vacuoles containing 4-8 parasites were observed by microscopy after washing them in the specific buffer for each experiment. Drugs were added 1 minute after the start of imaging in that same buffer at the concentrations indicated: ionomycin $(0.005-1 \mu \mathrm{M})$, histamine $(100 \mu \mathrm{M})$, thapsigargin $(1 \mu \mathrm{M})$, saponin $(0.01 \%)$, nifedipine $(10 \mu \mathrm{M})$, and zaprinast $(100 \mu \mathrm{M})$. Ringer buffer was used as extracellular buffer (EB). $\mathrm{CaCl}_{2}$ was omitted in the absence of extracellular calcium, and the media was supplemented with either $100 \mu \mathrm{M}$ EGTA, $1 \mathrm{mM}$ EGTA or $1 \mathrm{mM}$ BAPTA. The composition of intracellular buffer (IB) is: $140 \mathrm{mM}$ potassium gluconate, $10 \mathrm{mM} \mathrm{NaCl}, 2.7 \mathrm{mM} \mathrm{MgSO} 4,2 \mathrm{mM}$ ATP (sodium salt), $1 \mathrm{mM}$ glucose, $200 \mu \mathrm{M}$ EGTA, $65 \mu \mathrm{M} \mathrm{CaCl} 2\left(90 \mathrm{nM}\right.$ free $\mathrm{Ca}^{2+}$ ), and $10 \mathrm{mM}$ Tris/Hepes, $\mathrm{pH} 7.3$. The parasites were imaged at $37^{\circ} \mathrm{C}$. Fluorescence images were captured using an Olympus IX-71 inverted fluorescence microscope with a Photometrix CoolSnapHQ chargecoupled device (CCD) camera driven by DeltaVision software (Applied Precision). Images were collected using time-lapse mode with an acquisition rate of at least 2-3 seconds during 10-20 minutes. Images were converted into videos using SoftWorx suite 2.0 software from Applied Precision. Fiji was used for the analysis of the video data. Fluorescence tracings were produced by 
drawing an ROI around the host or parasite of interest and measuring the mean gray fluorescence. Prism was used for statistical analysis.

For natural egress, $3.5 \times 10^{5}$ Hela cells stabling expressing the red GECI jRGECO1a (14) were plated on $35 \mathrm{~mm}$ glass bottom MatTek dishes in DMEM-HG with 10\% FBS. $24 \mathrm{~h}$ later cells were infected with $2.75 \times 10^{6}$ parasites, and on day three the parasites were synchronized using $1 \mu \mathrm{M}$ compound, and one dish was treated with $2 \mu \mathrm{L}$ of DMSO as a vehicle control. On day four lysis of the control dish was examined for $70-80 \%$ lysis, and the synchronized dishes were used for video microscopy. The dishes were washed once with pre-warmed Ringer buffer, then again with pre-warmed Ringer buffer for 1 minute and finally a solution of Ringer buffer supplemented with $2 \mathrm{mM} \mathrm{CaCl} 2$ was added before commencing imaging.

\section{Whole cell patch}

Whole cell patch recording was applied according to the method previously described $(49,50)$. Briefly, coverslips with infected HeLa cells were transferred into a perfusion chamber (RC26GLP, Warner Instruments, USA) on a stage of an inverted IX51 Olympus microscope. Growth media was immediately replaced with an extracellular buffer prior to the start of the recordings, and cells were kept at room temperature for no more than 2 hours. Coverslips were replaced every 2 hours. Intracellular thin-walled recording capillars (1.5-mm outer diameter, 1.17-mm inner diameter) made of borosilicate glass (World Precision Instruments, Sarasota, FL) were used to pull patch pipettes (3-4 M $\Omega$ ) on a horizontal Flaming/Brown micropipette puller (P-97, Sutter Instruments) and then were backfilled with intracellular solution. Recordings from HeLa cells were obtained with an Axopatch 200B amplifier (Molecular Devices) using high-resolution videomicroscopy (Ameriscope). The voltage output was digitized at 16-bit resolution, $20 \mathrm{kHz}$, and filtered at $1 \mathrm{kHz}$ (Digidata 1550A, Molecular Devices). All experiments were performed at -60 $\mathrm{mV}$ holding membrane potential ( $\mathrm{Vh}$ ) which is close to values reported as physiological for HeLa cells (51) to prevent activation of voltage-gated calcium channels. After establishing a "seal" (>1 $\mathrm{M} \Omega$ ) slight negative pressure was applied together with "ZAP" electrical pulse $(0.5-5 \mathrm{~ms},+1.3 \mathrm{~V})$ to break cell membrane. The time from membrane opening (start of pipette/cytosol solution exchange) to egress was visually recorded. All statistical analyses were conducted using GraphPad Prism 5 (GraphPad Software, San Diego, CA). All values are expressed as means \pm SE. Between- 
group differences were compared using unpaired $t$-tests. Differences were considered statistically significant at $P<0.05$, and $n$ refers to the number of cells.

HeLa cells grown in high glucose DMEM with 10\% FBS on 22 x $40 \mathrm{~mm}$ glass coverslips until $70 \%$ confluency were infected with $1 \times 10^{6}$ GCaMP6f-expressing tachyzoites. $24 \mathrm{~h}$ post infection coverslips were placed in an electrophysiology recording chamber $(\sim 1 \mathrm{ml})$ and bathed in extracellular solution (mM): $140 \mathrm{NaCl}, 5 \mathrm{KCl}, 1 \mathrm{MgSO}_{4}, 1.8 \mathrm{CaCl}_{2}, 10$ Hepes, pH 7.5 adjusted with $\mathrm{NaOH} / \mathrm{HCl}$. Composition of "high potassium" intracellular pipette solution $(\mathrm{mM}): 140 \mathrm{KCl}$, $5 \mathrm{NaCl}, 2 \mathrm{MgCl}_{2}, 1$ Glucose, 10 Hepes, 1 BAPTA, pH 7.3 adjusted with $\mathrm{KOH} / \mathrm{HCl}$. "Low potassium" solution was prepared as described above with equimolar substitution of $130 \mathrm{mM} \mathrm{KCl}$ with choline chloride $(\mathrm{ChCl})$. Disodium ATP $(2 \mathrm{mM})$ was added to all intracellular solutions to maintain cell energy supply. Solutions with different free $\mathrm{Ca}^{2+}$ concentrations were prepared by adding of $\mathrm{Ca}^{2+}$ and BAPTA at proportions calculated with Webmaxc software (Stanford University, USA). For control experiments in order to exclude the role of host cell extracellular calcium entry that may contribute to $T$. gondii egress, we used modified extracellular solution with $\mathrm{MgCl}_{2}$ and $\mathrm{CaCl}_{2}$ adjusted to $5 \mathrm{mM}$ and $0.1 \mathrm{mM}$, respectively.

\section{Quantification and Statistical Analysis}

Statistical analysis of fluorescence images was performed using FIJI/ImageJ (52). Briefly, images were background subtracted and normalized using an average of the first 5 frames of imaging. $\Delta \mathrm{F}$ $\left(\mathrm{F}_{\max } / \mathrm{F}_{\min }\right)$ represents the highest fold change over baseline in fluorescence after addition of stimuli or reagent. Figures were constructed using Prism analysis suite and error bars represent the standard error of the mean S.E.M. of three independent experiments. Significant differences were only considered if $\mathrm{P}$ values were $<0.05$, where $* \mathrm{p}<0.05 ; * * \mathrm{p}<0.01 ; * * * \mathrm{p}<0.001$; and $* * * * \mathrm{p}<$ 0.0001. NS designates when the comparison is not statistically significant. Experiment-specific statistical information is provided in the figure legends or associated method details including trials (n), standard error of the mean SEM, and statistical test performed.

\section{Supplemental Material}


Fig S1. Impact of Host Histamine Signaling on T. gondii: A) Hela cells transiently expressing the red GECI RGECO were infected with cyto-GCaMP6f expressing parasites.; B) Stable Hela cell lines expressing jRGECO1a were infected with PV localized P30-jGCaMP7f expressing parasites; C) Hela cells infected with P30-RGECO cyto-GCaMP6f parasites. Under all conditions $100 \mu \mathrm{M}$ Histamine was added at about 1 min mark and the response was recorded. Tracings to the right of each panel series show fluorescence fluctuations of single parasites (green) or of a delineated region of interest in the host cells ( red) or PV (green) from 3 independent trials for each condition. Bar graphs represent quantification of the average $\Delta \mathrm{F}$ values of three independent trials (Red, jRGECO1a or RGECO, right axis) (Green, GCaMP6f or jGCaMP7f, left axis). Dashed white outlines indicate the area used as a region of interest to analyze the fluorescence tracings. Dashed white outlines highlight GCaMP6f-expressing parasites whose fluorescence tracings were used for analysis. Dashed Red outlines indicate the region of the host cell that was used to analyze for the RGECO or jRGECO1a channel. Numbers at the upper right of each panel indicate the time frame of the video.

Fig S2. $\triangle$ PLP1 Mutants Lack the Second $\mathrm{Ca}^{2+}$ Peak During Egress: A) Egress was induced in Hela cells infected with $\triangle$ PLP1 GCaMP6f parasites using $100 \mu \mathrm{M}$ Zaprinast; B \& C) Representative fluorescence tracings of $\triangle \mathrm{PLP} 1 \mathrm{GCaMP} 6 \mathrm{f}$ after addition of $100 \mu \mathrm{M}$ Zaprinast for egress and non-egressing parasites respectively. Notice, two peaks are visible for the parasites that were successfully able to egress and only one peak was visible for the parasites that were unable to egress.

Fig S3. Calibration of $\mathbf{C a}^{2+}$ Threshold: (A) RH tachyzoites $\left(5 \times 10^{7}\right)$ were loaded with FURA2$\mathrm{AM}$ and resuspended in $2.5 \mathrm{~mL}$ of Ringer's Buffer supplemented with $100 \mu \mathrm{M}$ EGTA. The cytosolic $\mathrm{Ca}^{2+}$ response to the addition of various concentrations of ionomycin is shown. The figure shows the average of at least 2 trials of each condition; (B) Quantification of Ionomycin Titration Curve. The first 15 seconds of the slope after addition of ionomycin was determined and averaged for at least two independent trials.

Video S1. Carbachol Addition in GCaMP6f Infected Host Cells: Hela cells transiently expressing cytosolic localized RGECO were infected with cytosolic GCaMPf6 expressing 
parasites. $1 \mathrm{mM}$ Carbachol was added at approximately the 1 min mark. (Fig. 1B shows still images from this video).

Video S2. Thapsigargin Stimulation in LAR-GECO Expressing Host Cells: Hela cells transiently expressing the low affinity mitochondrial $\mathrm{Ca}^{2+}$ indicator LAR-GECO1.2 were infected with cytosolic GCaMP6f expressing parasite. $2 \mu \mathrm{M}$ Thapsigargin was added at approximately the 1 min mark. (Fig. 2B shows still images from this video).

Video S3. Two-peaks of $\mathrm{Ca}^{2+}$ contribute to Parasite Egress: Hela cells infected with cytosolic GCaMP6f parasites were treated with $100 \mu \mathrm{M}$ of Zaprinast in media supplemented with $2 \mathrm{mM}$ $\mathrm{Ca}^{2+}$. (Fig. 3E shows still images from this video).

Video S4. Natural Egress in Cpd 1 Synchronized Parasites: Hela cells stabling expressing cytosolic jRGECO1a infected with cytosolic GCaMP6f expressing parasites. After 24 hrs post infection $1 \mu \mathrm{M}$ cpd1 was added. $24 \mathrm{hr}$ post cpd1 addition parasite egress was imaged after cpd1 washout. (Fig. 4A shows still images from this video).

Video S5. Whole-Cell Patch under High $\mathrm{K}^{+}$and High $\mathrm{Ca}^{2+}$ Conditions: Hela cells infected with GCaMP6f parasites were whole-cell patched with a patch pipette solution comprising 140 $\mathrm{mM} \mathrm{K}^{+}$and $10 \mu \mathrm{M} \mathrm{Ca}^{2+}$. Note parasite egress is slow, methodical, and occurring one-by-one in comparison to detergents and ionophores. Video presented in real time. (Fig. 6B shows still images from this video).

Video S6. Whole-Cell Patch under Low $\mathrm{K}^{+}$and High $\mathrm{Ca}^{2+}$ conditions: Hela cells infected with GCaMP6f parasites were whole-cell patched with a patch pipette solution comprising $10 \mathrm{mM} \mathrm{K}^{+}$, $130 \mathrm{mM}$ choline chloride, and $10 \mu \mathrm{M} \mathrm{Ca}^{2+}$. Again, parasites egress slower in comparison to detergents and ionophores, but more rapidly in comparison to high $\mathrm{K}^{+}$conditions. Parasite egress occurred in which all parasites egressed at once under these conditions. Video presented in real time. (Fig. 6C shows still images from this video).

\section{Table S1. Plasmids used in this work}




\section{Acknowledgements}

We would like to thank Alex W. Chan and Dr. Sebastian Lourido for the protocol of natural egress using compound 1; Dr. Vern Carruthers for the $\triangle$ PLP1 mutant parasites; Dr. Diego Huet for reading the manuscript; Daniel Williamson for assisting on the egress of the $\triangle$ PLP1 mutant; Beejan Asady for technical assistance; Julie Nelson for the FAC's sorting assistance; Dr. Kandasamy for technical assistance on the use of the microscopes at the Biomedical Microscopy Core. This work was supported by an NIH grant R01AI128356 to SNJM. SAV and EP were partially supported by fellowships (pre-doc and post-doc respectively) through a Training Grant in Tropical and Emerging Global Diseases (T32AI060546).

\section{Authors Contributions}

Conceived and designed the experiments: SAV, CAM, SNJM. Performed the experiments: SAV, CAM, ZHL, MAHT and EP. Analyzed the data: SAV, CAM and SNJM. Contributed reagents/materials/analysis tools: SAV, CAM, ZHL and SNJM. Wrote the paper: SAV and SNJM. 


\section{References}

1. Black MW, Boothroyd JC. 2000. Lytic cycle of Toxoplasma gondii. Microbiol Mol Biol Rev 64:607-23.

2. Blader IJ, Coleman BI, Chen CT, Gubbels MJ. 2015. Lytic Cycle of Toxoplasma gondii: 15 Years Later. Annu Rev Microbiol 69:463-85.

3. Arrizabalaga G, Boothroyd JC. 2004. Role of calcium during Toxoplasma gondii invasion and egress. Int J Parasitol 34:361-8.

4. Hortua Triana MA, Marquez-Nogueras KM, Vella SA, Moreno SNJ. 2018. Calcium signaling and the lytic cycle of the Apicomplexan parasite Toxoplasma gondii. Biochim Biophys Acta Mol Cell Res 1865:1846-1856.

5. Clapham DE. 2007. Calcium signaling. Cell 131:1047-58.

6. Lovett JL, Sibley LD. 2003. Intracellular calcium stores in Toxoplasma gondii govern invasion of host cells. J Cell Sci 116:3009-16.

7. Borges-Pereira L, Budu A, McKnight CA, Moore CA, Vella SA, Hortua Triana MA, Liu J, Garcia CR, Pace DA, Moreno SN. 2015. Calcium Signaling throughout the Toxoplasma gondii Lytic Cycle: A STUDY USING GENETICALLY ENCODED CALCIUM INDICATORS. J Biol Chem 290:26914-26.

8. Lourido S, Moreno SN. 2015. The calcium signaling toolkit of the Apicomplexan parasites Toxoplasma gondii and Plasmodium spp. Cell Calcium 57:186-93.

9. Frenal K, Polonais V, Marq JB, Stratmann R, Limenitakis J, Soldati-Favre D. 2010. Functional dissection of the apicomplexan glideosome molecular architecture. Cell Host Microbe 8:343-57.

10. Endo T, Sethi KK, Piekarski G. 1982. Toxoplasma gondii: calcium ionophore A23187mediated exit of trophozoites from infected murine macrophages. Exp Parasitol 53:17988.

11. Kafsack BF, Pena JD, Coppens I, Ravindran S, Boothroyd JC, Carruthers VB. 2009. Rapid membrane disruption by a perforin-like protein facilitates parasite exit from host cells. Science 323:530-3.

12. Moudy R, Manning TJ, Beckers CJ. 2001. The loss of cytoplasmic potassium upon host cell breakdown triggers egress of Toxoplasma gondii. J Biol Chem 276:41492-501.

13. Schwab JC, Beckers CJ, Joiner KA. 1994. The parasitophorous vacuole membrane surrounding intracellular Toxoplasma gondii functions as a molecular sieve. Proc Natl Acad Sci U S A 91:509-13.

14. Dana H, Mohar B, Sun Y, Narayan S, Gordus A, Hasseman JP, Tsegaye G, Holt GT, Hu A, Walpita D, Patel R, Macklin JJ, Bargmann CI, Ahrens MB, Schreiter ER, Jayaraman V, Looger LL, Svoboda K, Kim DS. 2016. Sensitive red protein calcium indicators for imaging neural activity. Elife 5.

15. Zhao Y, Araki S, Wu J, Teramoto T, Chang YF, Nakano M, Abdelfattah AS, Fujiwara M, Ishihara T, Nagai T, Campbell RE. 2011. An expanded palette of genetically encoded $\mathrm{Ca}(2)(+)$ indicators. Science 333:1888-91.

16. Dana H, Sun Y, Mohar B, Hulse BK, Kerlin AM, Hasseman JP, Tsegaye G, Tsang A, Wong A, Patel R, Macklin JJ, Chen Y, Konnerth A, Jayaraman V, Looger LL, Schreiter ER, Svoboda K, Kim DS. 2019. High-performance calcium sensors for imaging activity in neuronal populations and microcompartments. Nat Methods 16:649-657. 
17. Walker JK, Gainetdinov RR, Feldman DS, McFawn PK, Caron MG, Lefkowitz RJ, Premont RT, Fisher JT. 2004. G protein-coupled receptor kinase 5 regulates airway responses induced by muscarinic receptor activation. Am J Physiol Lung Cell Mol Physiol 286:L312-9.

18. Ockenga W, Kuhne S, Bocksberger S, Banning A, Tikkanen R. 2013. Non-neuronal functions of the $\mathrm{m} 2$ muscarinic acetylcholine receptor. Genes (Basel) 4:171-97.

19. Tasaka K, Mio M, Okamoto M. 1986. Intracellular calcium release induced by histamine releasers and its inhibition by some antiallergic drugs. Ann Allergy 56:464-9.

20. Wu J, Prole DL, Shen Y, Lin Z, Gnanasekaran A, Liu Y, Chen L, Zhou H, Chen SR, Usachev YM, Taylor CW, Campbell RE. 2014. Red fluorescent genetically encoded Ca2+ indicators for use in mitochondria and endoplasmic reticulum. Biochem J 464:13-22.

21. Liu C, Hermann TE. 1978. Characterization of ionomycin as a calcium ionophore. The Journal of biological chemistry 253:5892-4.

22. Berman MC. 2000. Characterisation of thapsigargin-releasable $\mathrm{Ca}(2+)$ from the $\mathrm{Ca}(2+)$ ATPase of sarcoplasmic reticulum at limiting $[\mathrm{Ca}(2+)]$. Biochim Biophys Acta 1509:4254.

23. Tepikin AV. 2018. Mitochondrial junctions with cellular organelles: $\mathrm{Ca}(2+)$ signalling perspective. Pflugers Arch 470:1181-1192.

24. Sidik SM, Hortua Triana MA, Paul AS, El Bakkouri M, Hackett CG, Tran F, Westwood NJ, Hui R, Zuercher WJ, Duraisingh MT, Moreno SN, Lourido S. 2016. Using a Genetically Encoded Sensor to Identify Inhibitors of Toxoplasma gondii Ca2+ Signaling. J Biol Chem 291:9566-80.

25. Lourido S, Tang K, Sibley LD. 2012. Distinct signalling pathways control Toxoplasma egress and host-cell invasion. EMBO J 31:4524-34.

26. Collins CR, Hackett F, Strath M, Penzo M, Withers-Martinez C, Baker DA, Blackman MJ. 2013. Malaria parasite cGMP-dependent protein kinase regulates blood stage merozoite secretory organelle discharge and egress. PLoS Pathog 9:e1003344.

27. Fertig N, Blick RH, Behrends JC. 2002. Whole cell patch clamp recording performed on a planar glass chip. Biophys J 82:3056-62.

28. Pace DA, McKnight CA, Liu J, Jimenez V, Moreno SN. 2014. Calcium entry in Toxoplasma gondii and its enhancing effect of invasion-linked traits. J Biol Chem 289:19637-47.

29. Nagamune K, Beatty WL, Sibley LD. 2007. Artemisinin induces calcium-dependent protein secretion in the protozoan parasite Toxoplasma gondii. Eukaryotic cell 6:2147-56.

30. Putney JW, Bird GS. 2008. Cytoplasmic calcium oscillations and store-operated calcium influx. J Physiol 586:3055-9.

31. Berridge MJ, Galione A. 1988. Cytosolic calcium oscillators. FASEB J 2:3074-82.

32. Wetzel DM, Chen LA, Ruiz FA, Moreno SN, Sibley LD. 2004. Calcium-mediated protein secretion potentiates motility in Toxoplasma gondii. J Cell Sci 117:5739-48.

33. Lovett JL, Marchesini N, Moreno SN, Sibley LD. 2002. Toxoplasma gondii microneme secretion involves intracellular $\mathrm{Ca}(2+)$ release from inositol 1,4,5-triphosphate (IP(3))/ryanodine-sensitive stores. J Biol Chem 277:25870-6.

34. Luo S, Vieira M, Graves J, Zhong L, Moreno SN. 2001. A plasma membrane-type Ca(2+)ATPase co-localizes with a vacuolar $\mathrm{H}(+)$-pyrophosphatase to acidocalcisomes of Toxoplasma gondii. Embo J 20:55-64. 
35. Fang J, Marchesini N, Moreno SN. 2006. A Toxoplasma gondii phosphoinositide phospholipase C (TgPI-PLC) with high affinity for phosphatidylinositol. Biochem J 394:417-25.

36. Bullen HE, Jia Y, Yamaryo-Botte Y, Bisio H, Zhang O, Jemelin NK, Marq JB, Carruthers V, Botte CY, Soldati-Favre D. 2016. Phosphatidic Acid-Mediated Signaling Regulates Microneme Secretion in Toxoplasma. Cell Host Microbe 19:349-60.

37. Moreno SN, Zhong L. 1996. Acidocalcisomes in Toxoplasma gondii tachyzoites. Biochem J 313 ( Pt 2):655-9.

38. Lanner JT, Georgiou DK, Joshi AD, Hamilton SL. 2010. Ryanodine receptors: structure, expression, molecular details, and function in calcium release. Cold Spring Harb Perspect Biol 2:a003996.

39. Dupont G, Combettes L, Bird GS, Putney JW. 2011. Calcium oscillations. Cold Spring Harb Perspect Biol 3.

40. Bisio H, Lunghi M, Brochet M, Soldati-Favre D. 2019. Phosphatidic acid governs natural egress in Toxoplasma gondii via a guanylate cyclase receptor platform. Nat Microbiol 4:420-428.

41. Williams MJ, Alonso H, Enciso M, Egarter S, Sheiner L, Meissner M, Striepen B, Smith BJ, Tonkin CJ. 2015. Two Essential Light Chains Regulate the MyoA Lever Arm To Promote Toxoplasma Gliding Motility. MBio 6:e00845-15.

42. Vines CM. 2012. Phospholipase C. Adv Exp Med Biol 740:235-54.

43. Roiko MS, Svezhova N, Carruthers VB. 2014. Acidification Activates Toxoplasma gondii Motility and Egress by Enhancing Protein Secretion and Cytolytic Activity. PLoS Pathog 10:e1004488.

44. Arrizabalaga G, Ruiz F, Moreno S, Boothroyd JC. 2004. Ionophore-resistant mutant of Toxoplasma gondii reveals involvement of a sodium/hydrogen exchanger in calcium regulation. J Cell Biol 165:653-62.

45. Barylyuk K, Koreny L, Ke H, Butterworth S, Lassadi I, Mourier T, Breckels L, Gatto L, Pain A, Lilley K, Waller R. 2019. Global mapping of protein subcellular location in apicomplexans: the parasite as we've never seen it before. Access Microbiology 1:432.

46. Miranda K, Pace DA, Cintron R, Rodrigues JC, Fang J, Smith A, Rohloff P, Coelho E, de Haas F, de Souza W, Coppens I, Sibley LD, Moreno SN. 2010. Characterization of a novel organelle in Toxoplasma gondii with similar composition and function to the plant vacuole. Molecular microbiology 76:1358-75.

47. Vella SA, Calixto A, Asady B, Li ZH, Moreno SN. 2019. Genetic Indicators for Calcium Signaling studies in Toxoplasma gondii. Methods in Molecular Biology Toxoplasma.

48. Lou YL, Guo F, Liu F, Gao FL, Zhang PQ, Niu X, Guo SC, Yin JH, Wang Y, Deng ZF. 2012. miR-210 activates notch signaling pathway in angiogenesis induced by cerebral ischemia. Mol Cell Biochem 370:45-51.

49. Potapenko ES, Biancardi VC, Florschutz RM, Ryu PD, Stern JE. 2011. Inhibitoryexcitatory synaptic balance is shifted toward increased excitation in magnocellular neurosecretory cells of heart failure rats. J Neurophysiol 106:1545-57.

50. Potapenko ES, Biancardi VC, Zhou Y, Stern JE. 2013. Astrocytes modulate a postsynaptic NMDA-GABAA-receptor crosstalk in hypothalamic neurosecretory neurons. J Neurosci 33:631-40. 
51. Chemin J, Monteil A, Briquaire C, Richard S, Perez-Reyes E, Nargeot J, Lory P. 2000. Overexpression of T-type calcium channels in HEK-293 cells increases intracellular calcium without affecting cellular proliferation. FEBS Lett 478:166-72.

52. Schindelin J, Arganda-Carreras I, Frise E, Kaynig V, Longair M, Pietzsch T, Preibisch S, Rueden C, Saalfeld S, Schmid B, Tinevez JY, White DJ, Hartenstein V, Eliceiri K, Tomancak P, Cardona A. 2012. Fiji: an open-source platform for biological-image analysis. Nat Methods 9:676-82.

\section{Figure Legends}

Figure 1: $\mathrm{Ca}^{2+}$ Host Signaling and $\boldsymbol{T}$. gondii egress: A) Representative Images of Hela cells transiently expressing the red GECI RGECO that were infected with cyto-GCaMP6f expressing parasites. $1 \mathrm{mM}$ Carbachol was added 1 min after recording started. B) Representative Images of Hela cells stably expressing jRGECO1a that were infected with PV localized P30-jGCaMP7f expressing tachyzoites. $1 \mathrm{mM}$ Carbachol was added $1 \mathrm{~min}$ after recording started. C) Representative images of Hela cells infected with P30-RGECO cyto-GCaMP6f. 1 mM Carbachol was added 1 min after recording started

Tracings to the right of each panel shows fluorescence fluctuations of single parasites (green) or of a delineated region of interest in the host cells (red) or PV (green) from 3 independent trials for each condition. Bar graphs represent quantification of the average $\Delta \mathrm{F}$ values of three independent trials (Red, jRGECO1a or RGECO, right axis) (Green, GCaMP6f or jGCaMP7f, left axis). Dashed white outlines indicate the area used as a region of interest for the analyzes for fluorescence changes. Dashed white outlines show GCaMP6f-expressing parasites whose fluorescence tracings were used for analysis. Dashed red outlines indicate the region of the host cell that was used to analyze the RGECO or jRGECO1a channel. Numbers at the upper right of each panel indicate the time frame of the video.

Figure 2: Threshold for Egress: A \& B) Hela cells were transiently transfected with the low affinity mitochondria $\mathrm{Ca}^{2+}$ indicator LAR-GECO1.2 and infected with tachyzoites expressing cyto-GCaMP6f for approximately $20 \mathrm{~h}$. The mitochondria surrounding each PV is labeled with the LAR-GECO1.2 (red). $1 \mu \mathrm{M}$ Ionomycin (IO) and $2 \mu \mathrm{M}$ Thapsigargin (TG) were added, respectively at $1 \mathrm{~min}$ and the response recorded. Dashed white outlines indicate the region of interest used for the analysis of the fluorescence changes. Dashed white outlines show GCaMP6f- 
expressing parasites whose fluorescence tracings were used for analysis. Dashed red outlines indicate the region of the host cell that was used to analyze for the LAR-GECO1.2 channel. Numbers at the upper right of each panel indicate the time frame of the video. C \& D) Fluorescence tracings obtained after addition of IO or TG, respectively. Dashed white outlines shown in A\&B indicate parasites used for analysis of GCaMP6f parasites. Dashed red outlines indicate region of LAR-GECO1.2 channel that was used for analysis. Numbers at the upper right of each panel indicate the time frame of the video. E) Comparison of $\Delta$-Fluorescence values from each Pharmacological stimulus. IO and Zaprinast (Zap) induce egress while TG and Histamine did not. F \& G) Hela cells were infected with GCaMP6f parasites and IO was titrated down to find a concentration that did not induce egress $(0.005 \mu \mathrm{M})$. Dashed white outlines indicate the area used as a region of interest to analyze the fluorescence changes. Numbers at the upper right of each panel indicate the time frame of the video. H \& I) Fluorescence tracings of IO threshold titration of $1 \mu \mathrm{M}$ and $0.005 \mu \mathrm{M}$, respectively. J) Average $\Delta$-fluorescence values of $1,0.1,0.01$, and 0.005 $\mu \mathrm{M}$ IO.

Figure 3: Two Peaks of $\mathbf{C a}^{2+}$ Precede Egress: A \& D) Hela cells infected with GCaMP6f parasites bathed in Ringer Buffer supplemented with either $2 \mathrm{mM} \mathrm{Ca}^{2+}\left(\mathrm{Ca}^{2+}\right.$ rich) or $100 \mu \mathrm{M}$ EGTA ( $\mathrm{Ca}^{2+}$ free media), respectively post addition of Zaprinast. Dashed white outlines show the region of interest for the analysis of the fluorescence changes shown in the tracings. Numbers at the upper right of each panel indicate the time frame of the video. B \& E) Representative fluorescence tracings of single parasites under Zaprinast simulation in the presence and absence of extracellular $\mathrm{Ca}^{2+}$, respectively. Under $\mathrm{Ca}^{2+}$-free conditions (100 $\mu \mathrm{M}$ EGTA) the second peak is reduced. C) Quantification of GCaMP6f peak number preceding egress. Graph represents the summation of 3 independent experiments. F) Average time of egress comparing Zaprinast induced egress resuspended in extracellular media supplemented with either $2 \mathrm{mM} \mathrm{Ca}^{2+}(+)$ or $100 \mu \mathrm{M}$ EGTA (-). G) Intracellular GCaMP6f parasites were exposed to the surrounding buffer under $\mathrm{Ca}^{2+}$ free conditions ( $1 \mathrm{mM}$ EGTA) with a $0.01 \%(\mathrm{w} / \mathrm{v})$ saponin solution in Ringer Buffer $\left(\mathrm{SAP}-\mathrm{Ca}^{2+}\right)$. Dashed white outlines represent the parasites that were used in analysis. Numbers at the upper right of each panel indicate the time frame of the video. $\mathrm{H}$ ) Representative fluorescence tracings of non-egressing parasites treated with saponin in $\mathrm{Ca}^{2+}$-free conditions as shown in G. I) Intracellular GCaMP6f parasites were exposed to the surrounding buffer under $\mathrm{Ca}^{2+}$ rich 
conditions $\left(2 \mathrm{mM} \mathrm{Ca}^{2+}\right)$ using a $0.01 \%(\mathrm{w} / \mathrm{v})$ saponin solution in Ringer Buffer $\left(\mathrm{SAP}+\mathrm{Ca}^{2+}\right)$. Dashed white outlines represent the parasites that were used for the analysis. Numbers at the upper right of each panel indicate the time frame of the video. J) Representative fluorescence tracings of egressing parasites treated with saponin in $\mathrm{Ca}^{2+}$-rich conditions as shown in $\mathrm{J}$.

Figure 4: Natural Egress: Intracellular GCaMP6f parasites were synchronized for natural egress with Compound 1. A) Still images of Hella cells expressing jRGECO1a infected with tachyzoites expressing GCaMP6f and treated with $1 \mu \mathrm{M}$ compound for 24 hours. After washout of compound 1, parasites egressed naturally within 3-5 mins; dashed regions indicate the area used as region of interest for the analysis of fluorescence changes shown in the tracings. Dashed white outlines are used to highlight GCaMP6f-expressing parasites whose fluorescence tracings were used for analysis. Dashed red outlines indicate the region of the host cell that was used to analyze for the jRGECO1a channel. Numbers at the upper right of each panel indicate the time frame of the video. B) Still images of Hella cells expressing jRGECO1a infected with $\triangle$ PLP1 tachyzoites expressing GCaMP6f and treated with $1 \mu \mathrm{M}$ compound for 24 hours. After washout of compound 1, parasites egressed naturally within 3-5 mins; dashed regions indicate the area used as region of interest for the analysis of fluorescence changes shown in the tracings. Dashed regions are used to highlight $\triangle$ PLP1 GCaMP6f-expressing parasites whose fluorescence tracings were used for analysis. Dashed red outlines indicate the region of the host cell that was used to analyze for the jRGECO1a channel. Numbers at the upper right of each panel indicate the time frame of the video. C) Fluorescence tracings of host cell jREGO1a (red tracing) and GCaMP6f parasites (green tracings); D) Single Fluorescence tracings of host cell jREGO1a (red tracing) and GCaMP6f parasites (green tracings). Note that after compound 1 washout parasites egress still occurs with two peaks of fluorescence; E) Quantification of $\triangle \mathrm{F}$ of jRGECO1a (red bar) and GCaMP6f (green bar) after cpd1 washout. F) Fluorescence tracings of host cell jREGO1a (red tracing) and $\triangle$ PLP1 GCaMP6f parasites (green tracings)

Figure 5: Pharmacological inhibition of $\mathrm{Ca}^{2+}$ influx leads to Inhibition of Egress: A) GCaMP6f infected host cells were exposed to a buffer supplemented with $2 \mathrm{mM} \mathrm{Ca}^{2+}$ containing $0.01 \%(\mathrm{w} / \mathrm{v})$ saponin, and fluorescence changes were recorded. B) Fluorescence tracings of egressing parasites after addition of saponin in media supplemented with $2 \mathrm{mM} \mathrm{Ca}^{2+}$; C) Hela cells 
infected with tachyzoites expressing GCaMP6f were pretreated for 5 min with $10 \mu \mathrm{M}$ Nifedipine, a L-type Voltage Gated Calcium Channel Blocker in the presence of an extracellular buffer supplemented with $2 \mathrm{mM} \mathrm{Ca}^{2+}$ containing $0.01 \%(\mathrm{w} / \mathrm{v})$ saponin and fluorescence changes were recorded. Note that parasites did not egress under these conditions; D) Fluorescence tracings of GCaMP6f parasites pretreated with Nifedipine after saponin permeabilization. E) Hela cells infected with GCaMP6f expressing tachyzoites were treated with $100 \mu \mathrm{M}$ Zaprinast and egressed rapidly afterwards; F) Fluorescence tracings of GCaMP6f parasites treated with $100 \mu \mathrm{M}$ Zaprinast as indicated by the dashed outlines in E. G) Hela cells infected with GCaMP6f expressing tachyzoites were pretreated with $1 \mu \mathrm{M}$ of compound 1 for 5 mins. After addition of $100 \mu \mathrm{M}$ Zaprinast, parasite cytosolic $\mathrm{Ca}^{2+}$ slightly and briefly oscillated but no egress was evident; $\mathrm{H}$ ) Fluorescence tracings after pretreatment with $1 \mu \mathrm{M}$ compound 1 and stimulation of egress with $100 \mu \mathrm{M}$ Zaprinast as indicated by the dashed white outlines in G. dashed outlines indicate the area used as a region of interest for the analysis of the fluorescence changes shown in the tracings. For A, C, E and G, the white outlines highlight the GCaMP6f-expressing parasites whose fluorescence tracings were used for analysis presented in B, D, F and H. Numbers at the upper right of each panel indicate the time frame of the video.

Figure 6: Host-Cell Patch: Hela cells infected with GCaMP6f tachyzoites were whole-cell patched and egress was monitored. A) Whole-cell patch allowed for the exposure of PVs to defined $\mathrm{Ca}^{2+}$ concentrations by exchanging the cytosol of the host cell with the composition of the buffer inside the patch pipette; B) Representative still images of infected host cells were patched under high potassium conditions $\left(140 \mathrm{mM} \mathrm{K}{ }^{+}\right)$to mimic the high potassium environment of the host cytosol. Gradually increasing concentrations of free calcium were tested to see if/when egress occurred. The percentage of egressing vs non-egressing parasites is shown in the upper left-hand corner; C) Representative still images of infected hosts cells that were patched under low potassium conditions (10 $\mathrm{mM} \mathrm{K}^{+}$and $130 \mathrm{mM}$ Choline Chloride) and egress was monitored under the same experimental conditions as in A; D) Percentage of egressing parasites as a function of $\mathrm{Ca}^{2+}$ concentration. Green, $140 \mathrm{mM} \mathrm{K}^{+}$, Red, $10 \mathrm{mM} \mathrm{K}^{+}$and $130 \mathrm{mM} \mathrm{K}^{+}$; E) Average time of egress under high $\left(140 \mathrm{mM} \mathrm{K} \mathrm{K}^{+}\right)$and low potassium conditions $\left(10 \mathrm{mM} \mathrm{K}{ }^{+}\right.$and $130 \mathrm{mM}$ Choline Chloride). Note that under low $\mathrm{K}^{+}$conditions the percentage of egressing parasites increases, and parasites egress faster. 
Figure 7: Model of Host $\mathrm{Ca}^{2+}$ Influx During Intracellular Growth. (1) A host cell $\mathrm{Ca}^{2+}$ signaling event triggers an increase in host cell cytosolic $\mathrm{Ca}^{2+}$. Given that the PV is in equilibrium with the host cell cytosol, $\mathrm{PV} \mathrm{Ca}{ }^{2+}$ rises simultaneously. (2) The rise in $\mathrm{PV} \mathrm{Ca}^{2+}$ precedes $\mathrm{Ca}^{2+}$ influx into the parasite via an unknown channel thus causing a rise in the cytosolic $\mathrm{Ca}^{2+}$ of the parasite. (3) The increased cytosolic $\mathrm{Ca}^{2+}$ load of the parasite eventually returns back to basal levels as $\mathrm{Ca}^{2+}$ is pumped into the intracellular stores (IS). (4) The parasite continues replicating within the host cell while utilizing the $\mathrm{Ca}^{2+}$ influx from the host cell to maintain IS $\mathrm{Ca}^{2+}$ levels sufficient enough to be eventually utilized and released during egress. 
bioRxiv preprint doi: https://doi.org/10.1101/2020.03.06.980508; this version posted March 23, 2020. The copyright holder for this preprint (which was not certified by peer review) is the author/funder. All rights reserved. No reuse allowed without permission.

\section{Figure 1}

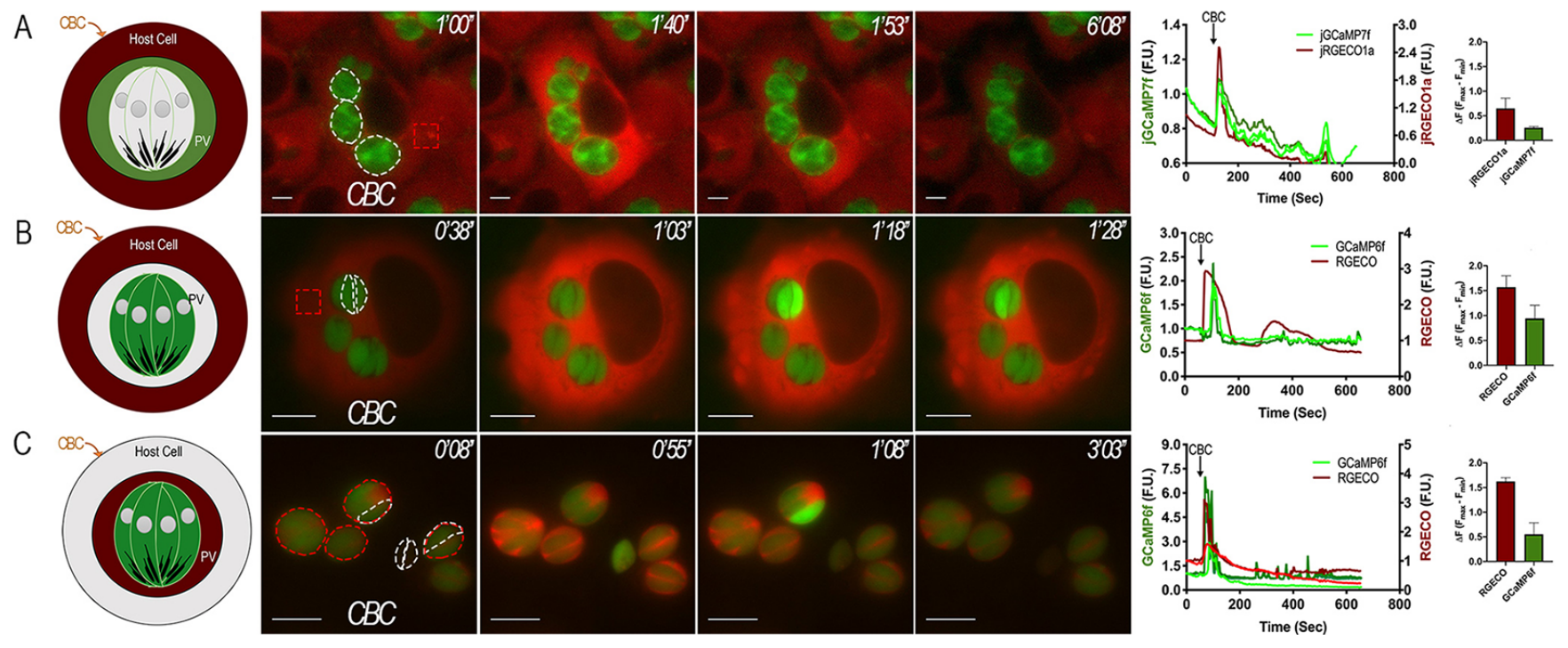




\section{Figure 2}
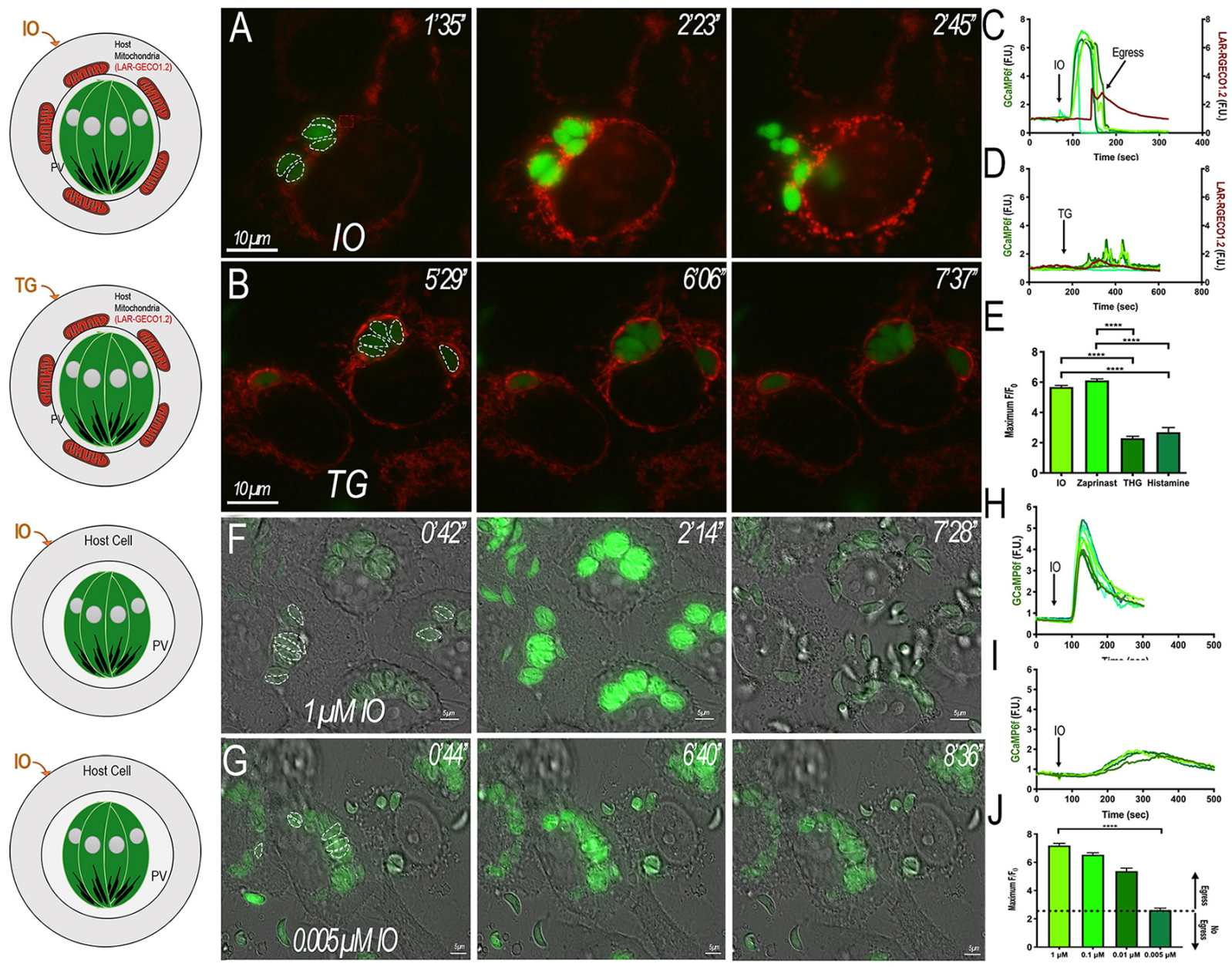


\section{Figure 3}
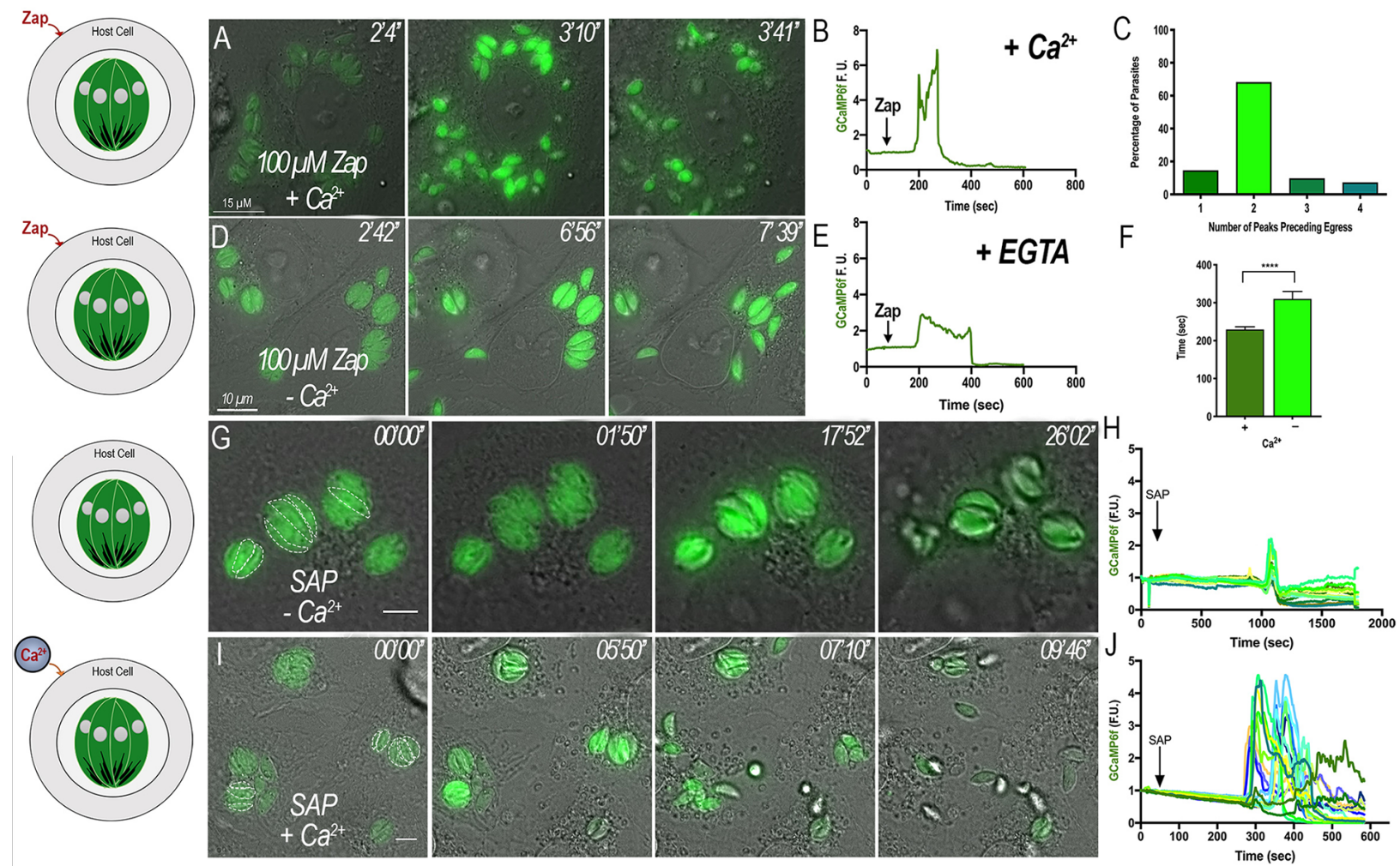
bioRxiv preprint doi: https://doi.org/10.1101/2020.03.06.980508; this version posted March 23, 2020. The copyright holder for this preprint (which was not certified by peer review) is the author/funder. All rights reserved. No reuse allowed without permission.

Figure 4

Host Cell

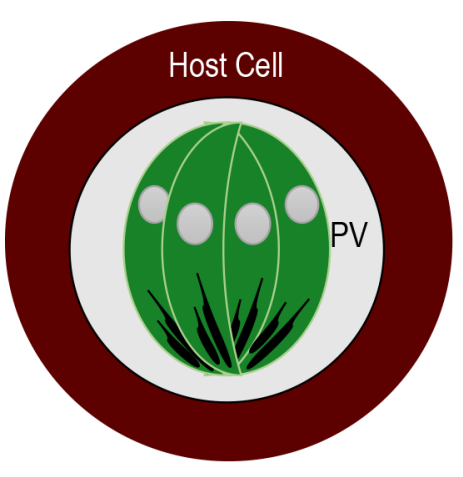

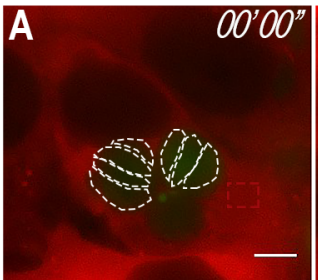
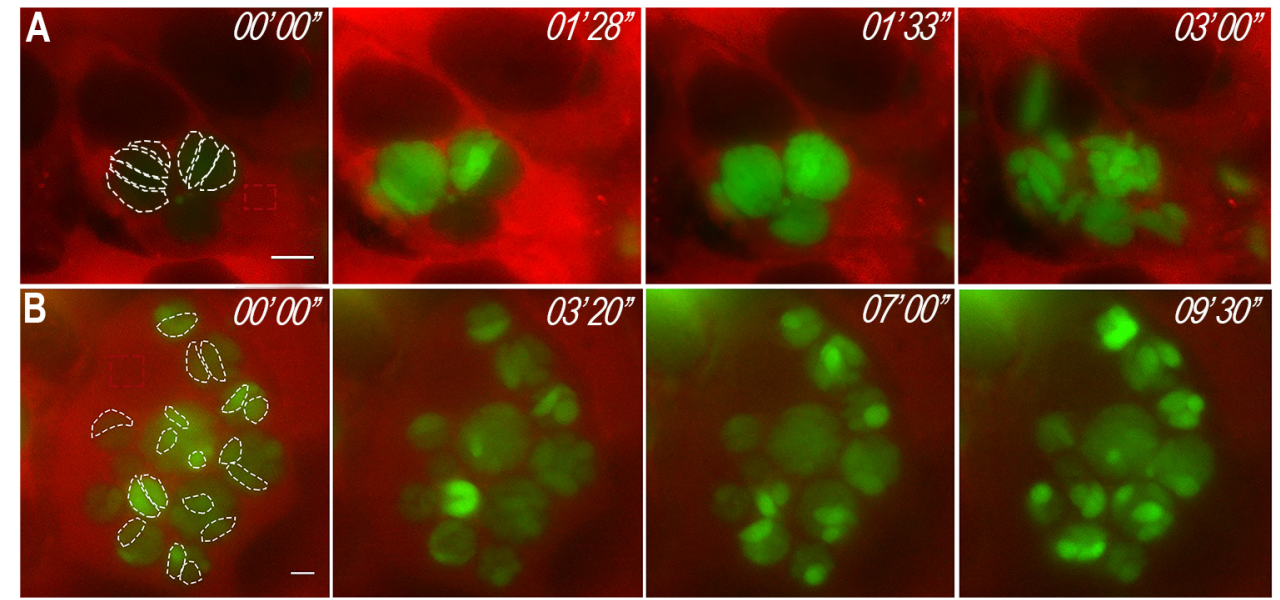

C
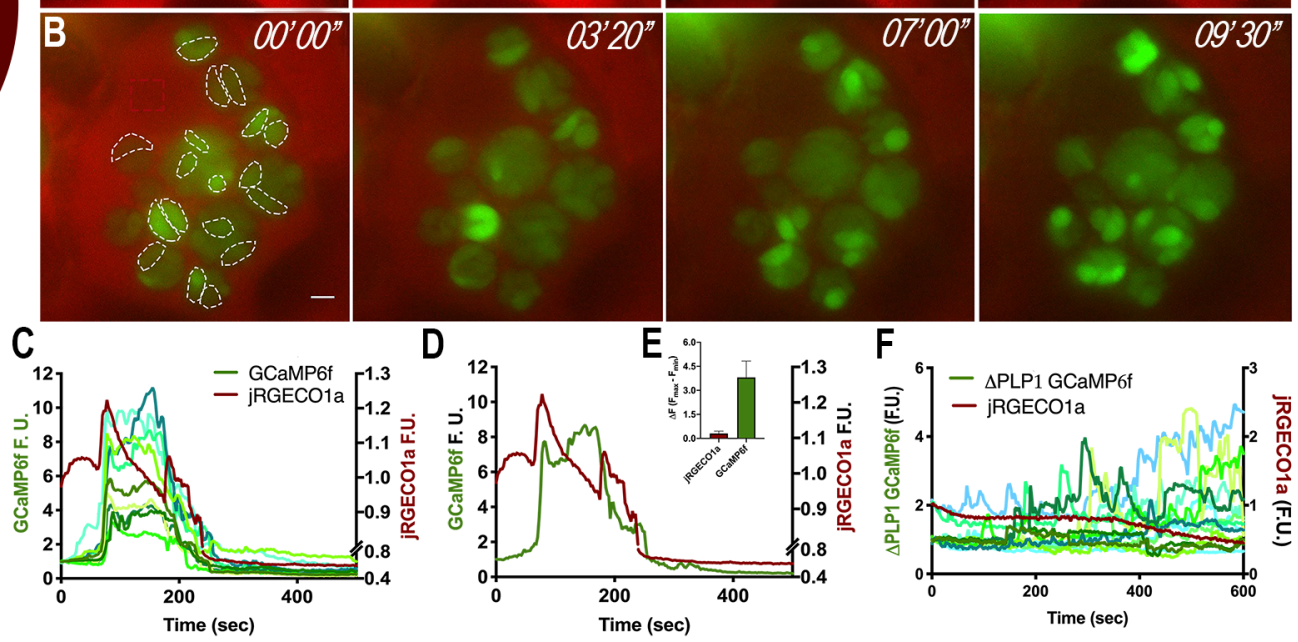

F

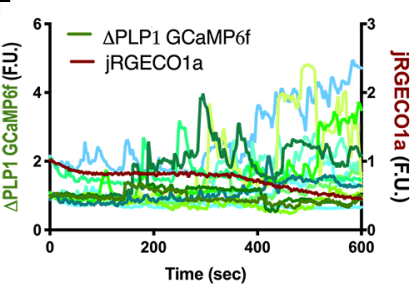


bioRxiv preprint doi: https://doi.org/10.1101/2020.03.06.980508; this version posted March 23, 2020. The copyright holder for this preprint (which was not certified by peer review) is the author/funder. All rights reserved. No reuse allowed without permission.

Figure 5

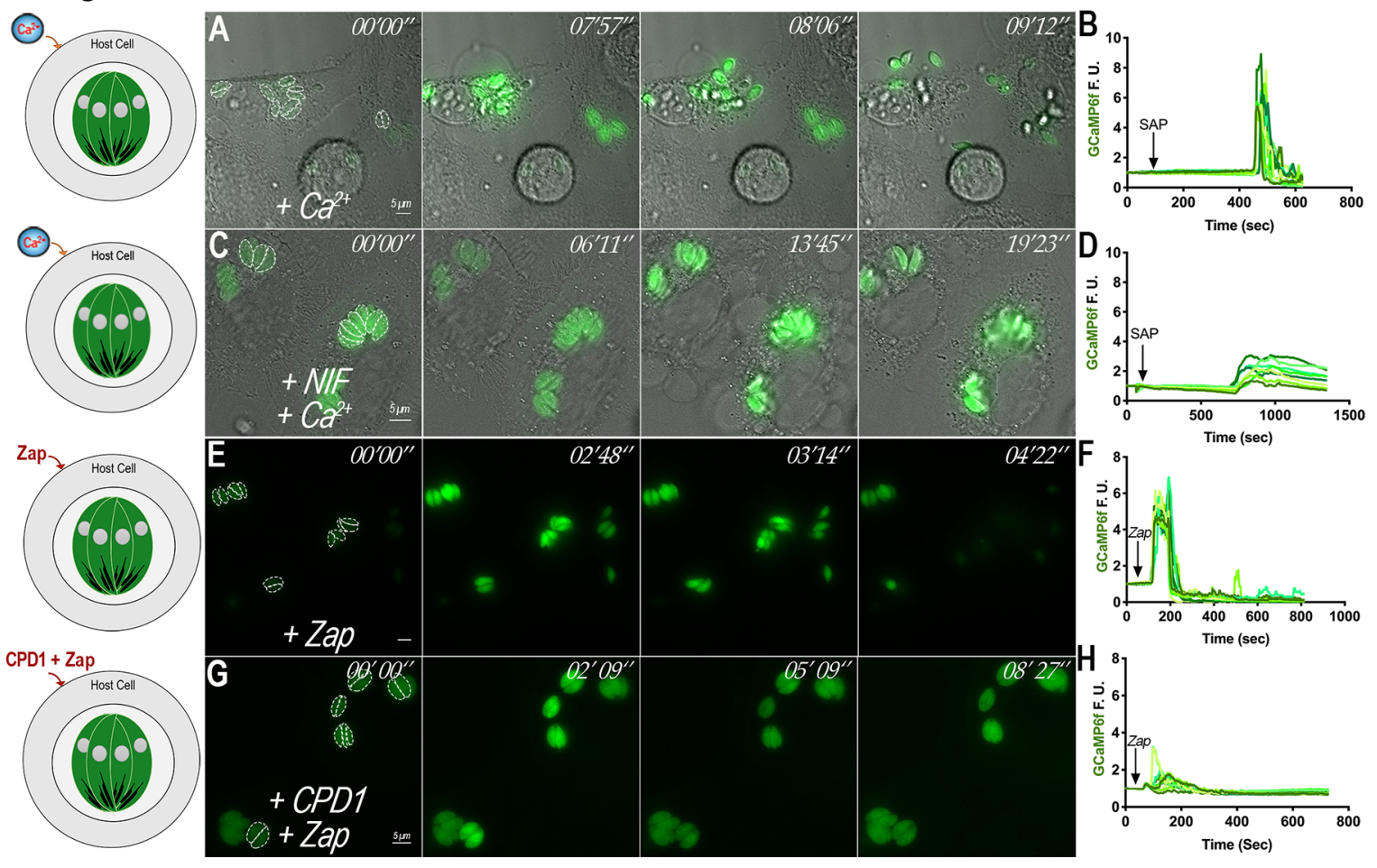




\section{Figure 6}

B

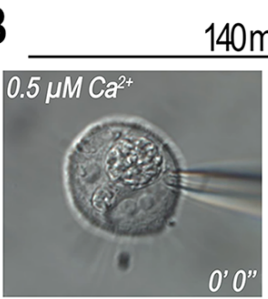

$140 \mathrm{mMK}^{+}$
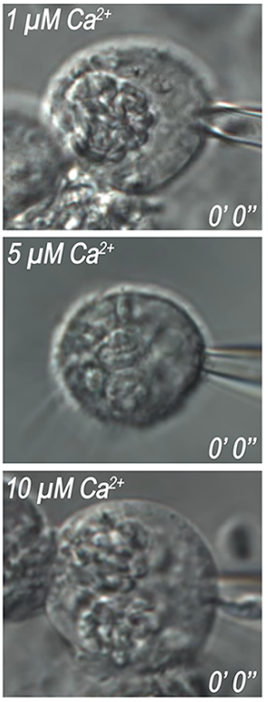

D
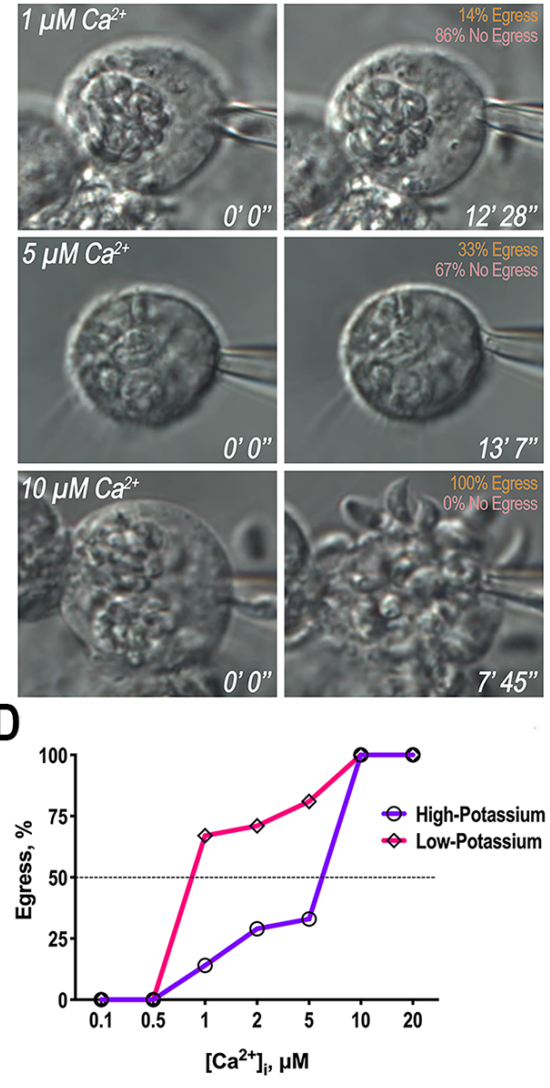

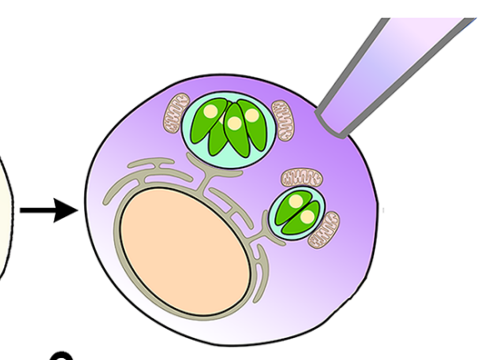

C
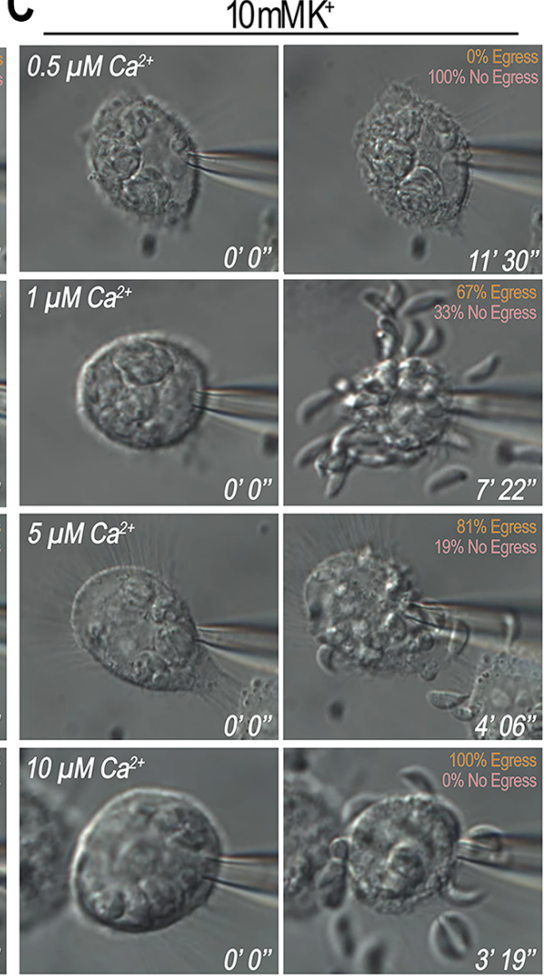

E

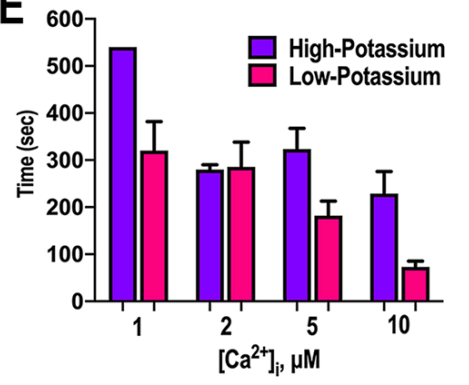


Figure 7

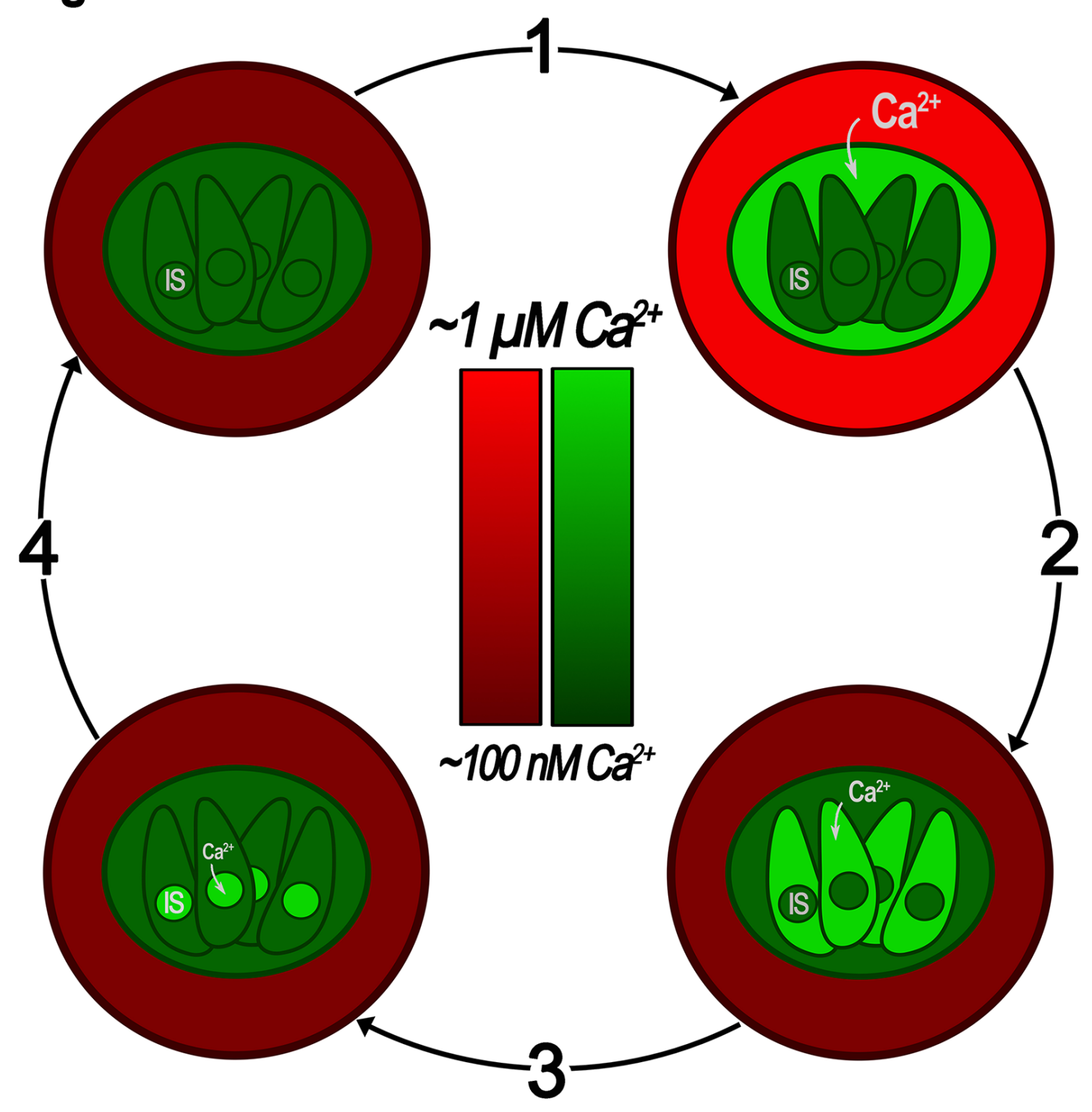

